\title{
Earthquake source characteristics along the arcuate Himalayan belt: Geodynamic implications
}

\author{
Prosanta Kumar Khan ${ }^{1, *}$, Md Afroz Ansari ${ }^{1}$ and S Mohanty ${ }^{2}$ \\ ${ }^{1}$ Department of Applied Geophysics, Indian School of Mines, Dhanbad, India. \\ ${ }^{2}$ Department of Applied Geology, Indian School of Mines, Dhanbad, India. \\ ${ }^{*}$ Corresponding author. e-mail: pkkhan_india@yahoo.com
}

The occurrences of moderate to large magnitude earthquakes and associated subsurface geological processes were critically examined in the backdrop of Indian plate obliquity, stress obliquity, topography, and the late Tertiary regional tectonics for understanding the evolving dynamics and kinematics in the central part of the Himalayas. The higher topographic areas are likely associated with the zones of depressions, and the lower topographic areas are found around the ridges located in the frontal part of the orogen. A positive correlation between plate and stress obliquities is established for this diffuse plate boundary. We propose that the zone of sharp bending of the descending Indian lithosphere is the nodal area of major stress accumulation which is released occasionally in form of earthquakes. The lateral geometry of the Himalayas shows clusters of seismicity at an angle of $\sim 20^{\circ}$ from the centre part of the arc. Such spatial distribution is interpreted in terms of compression across the arc and extension parallel to the arc. This biaxial deformation results in the development of dilational shear fractures, observed along the orogenic belt, at an angle of $\sim 20^{\circ}$ from the principal compressive stress axis.

\section{Introduction}

The study area is located in the central actuate belt of the extra peninsular India between longitude $75^{\circ}$ and $90^{\circ} \mathrm{E}$ with a maximum orthogonal extension of $\sim 300 \mathrm{~km}$ (figure 1), and fits closely with a small regular arcuate shape of radius $\sim 1696 \mathrm{~km}$ (Seeber et al. 1981; Bendick and Bilham 2001). Across the Himalayan arc, the convergence front documents three main kinematic elements (figure 1; cf. Davis et al. 1983):

(1) a foot-wall block (Indian cratons) that dips gently northward below the sediment-filled foredeep and has little internal deformation;

(2) an accretionary wedge where thrusting and folding verge towards the foredeep; and
(3) a hanging-wall block (Tibetan slab) that has prominent Neogene extensional structures in both radial and arc-parallel directions (e.g., Burg et al. 1984; Armijo et al. 1986; Gapais et al. 1992; Seeber and Pêcher 1998).

Recent convergence between India and Asia is assumed to be accommodated predominantly along a single fault - the Main Himalayan Thrust (MHT) (Wobus et al. 2005), which flattens beneath the Lesser Himalayas and roots deeper beneath the Higher Himalayas and southern Tibet (Cattin et al. 2001). Lyon-Caen and Molnar (1983) reported that the Indian plate was weakened and bent to $\sim 10^{\circ}-15^{\circ}$ at a position $\sim 50 \mathrm{~km}$ south of the Indus Tsangpo Suture (ITS), and the crust has been detached from the mantle along MHT.

Keywords. Seismicity; plate obliquity; stress obliquity; coupling; depression, ridge. 


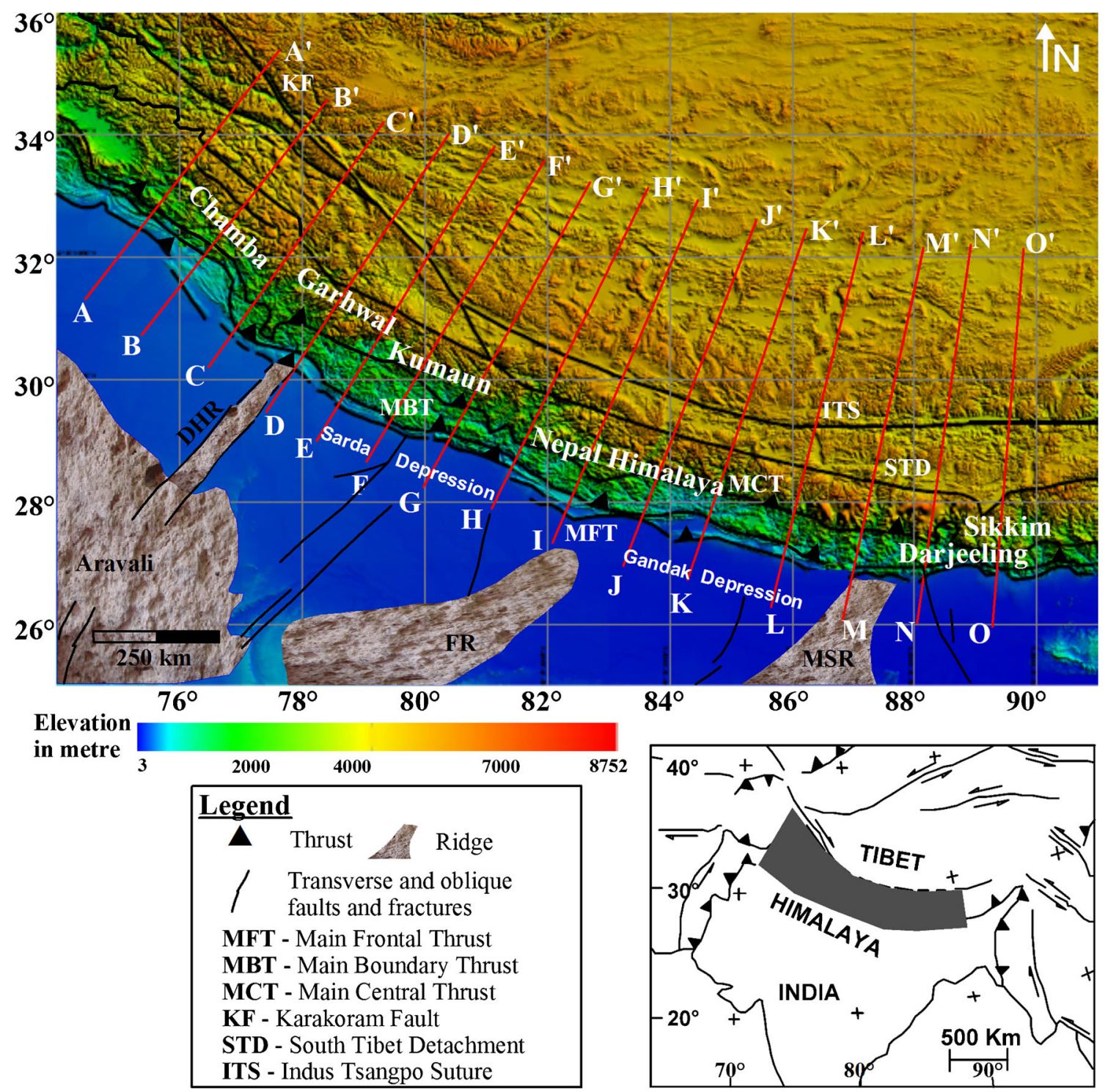

Figure 1. Tectonic map of the Himalayas (reconstructed after Gansser 1964; Valdiya 1980). Traverses AA $^{\prime}$ to OO' were taken orthogonal to the strike of the arcuate Himalayan belt for reconstruction of topography as illustrated in figure 2. Shaded zone in the lower right inset map represents the study area. Abbreviations: MFT- Main Frontal Thrust, MBT Main Boundary Thrust, MCT - Main Central Thrust, STD - South Tibet Detachment, ITS - Indus-Tsangpo Suture, DHR - Delhi-Hardwar Ridge, FR - Faizabad Ridge, MSR - Monghyr-Saharsa Ridge.

Studies on the mechanism of horizontal deformation in and around southern Tibet (Molnar and Tapponnier 1977; England and McKenzie 1982; Vilotte et al. 1986; Houseman and England 1993; England and Molnar 1997) and vertical uplift in the Himalayas (Molnar and Lyon-Caen 1989; Jackson and Bilham 1994; Bilham et al. 1997; Cattin and Avouac 2000; Takada and Matsu'ura 2004) provide numerous ideas about active deformation along the Himalayan orogenic belt. Thermo-mechanical numerical modelling demonstrates that the channel-flow and ductile extrusion are dynamically linked with the effects of surface denudation at the southern flank of the Himalayas (Beaumont et al. 2001). The mutual coupling between the crustal deformation and erosion, which leads to mountain building along the convergence margins (Koons 1989; Molnar and England 1990; Willett et al. 1993; Avouac and Burov 1996; Whipple and Meade 2006), is usually caused by trade-off between tectonic uplift and denudation (Ahnert 1970; Pinet and Souriau 1988; Summerfield and Hulton 1994; Hovius 2000). The Himalayas is one of the best modern examples for such a coupling operative all along the convergence margin (Lavé and Avouac 2001). Further, the degree of crustal deformation driven by convergence, detachment, and subduction of underlying mantle lithosphere is intrinsically related with plate obliquity (Ellis et al. 1995). It is worth 
mentioning that the processes controlling the mountain building (Harris 2007) or basal shearing and crustal flow in the hinterlands of the Himalayas and the southern Tibetan are not very clear. Occasionally, the high-strained features in the hinterlands of collisional orogens provide clues for lateral crustal flow and extrusion of material from midcrustal depths towards the orogenic foreland (Godin et al. 2006). In such cases, mapping of the earthquake hypocenters in the mantle and the associated source processes are important tools for understanding the plate interactions at depth.

In this paper, we examine the variation of topography along different strike-orthogonal profiles and trench-parallel crustal discontinuities such as Main Frontal Thrust (MFT), Main Boundary Thrust (MBT), Main Central Thrust (MCT), South Tibet Detachment (STD) and Indus-Tsangpo Suture (ITS). The interrelationships, if any, between seismic activities, topography, intersecting basement ridges (e.g., Monghyr-Saharsa, Faizabad, DelhiHardwar), and depressions (e.g., Gandak and Sarda) (Sastri et al. 1971; Rao 1973; Valdiya 1976; Dasgupta et al. 1987; Gahalaut and Kundu 2012) are qualitatively assessed. The evenly spaced ridges and depressions intersecting the Himalayas from south, evolved through east-west compression during bending of the northern Indian margin, are correlated with the level of occurrences of seismicity (Yin 2006; Gahalaut and Kundu 2012). We further attempt to analyze the neotectonic movements of the crustal blocks along the major crustal discontinuities in terms of earthquake source processes. We find an interrelationship between topography, seismicity and plate- and stress-obliquities, and finally propose a simplified model for stress-obliquitydependent subsurface lateral relative movements of blocks.

\section{Tectonics}

\subsection{Regional}

Plate reconstruction shows an abrupt decrease in the convergence rate from $\sim 15$ to $\sim 4 \mathrm{~cm} \mathrm{yr}^{-1}$ at ca. $50 \mathrm{Ma}$ (Molnar and Tapponnier 1975; Patriat and Achache 1984; Copley et al. 2010) following collision of the Indian plate against the Asian plate (Searle 1991; Garzanti et al. 1996; Hodges 2000; Yin and Harrison 2000). This rapid change in the rate of convergence coincided with a major rearrangement of plate boundaries in the Indian Ocean (DeMets et al. 1990; Copley et al. 2010). Subsequent to slow down or cessation of convergence (McKenzie and Sclater 1971; Sclater and Fisher 1974; Patriat and Achache 1984; Schluter et al. 2002), the Indian plate, partly coupled with Burma plate, resumed its northward journey through early Miocene time and increased its obliquity and convergence rate in middle Miocene time (McCaffrey 1991; Diament et al. 1992; Hall 1997). This renewed convergence reached its critical value in the late Miocene (Levchenko 1989), and caused widespread deformation in the northeastern Indian Ocean (Weissel et al. 1980; Gordon et al. 1990; Deplus et al. 1998; Hintersberger et al. 2010), opening of the Andaman Sea (Raju et al. 2004; Khan and Chakraborty 2005), reorganization of the Central Myanmar Basin (Khan 2004), initiation of grabens in southern Tibet and the Himalayas (Burchfiel and Royden 1985; Yin and Harrison 2000; Hintersberger et al. 2010), and rapid uplift of the Himalaya-Tibetan plateau (Harrison et al. 1992; Molnar et al. 1993). A $20^{\circ}$ clockwise rotation of the motion vectors of India prior to $7 \mathrm{Ma}$ (DeMets et al. 1990) coincided with the initiation of shortening between India and Australia since $7 \mathrm{Ma}$ as identified from the dating of a widespread unconformity (Leg 116 Shipboard Scientific Party 1987), and marked the onset of deformation along the eastern equatorial Indian Ocean. Since the collision with Asia, India has indented $\sim 3000 \mathrm{~km}$ into Asia, producing a combination of lateral escape and crustal thickening which have given rise to the largest uplifted topographic features, the Himalayas, on Earth with an average elevation of $5000 \mathrm{~m}$ (e.g., Molnar and Tapponnier 1975; Peltzer and Tapponnier 1988; Harrison et al. 1992; Fielding et al. 1994; Tapponnier et al. 2001).

\subsection{Local}

Present day convergence of the Indian plate along the Himalayan arc varies from $\sim 4.2$ to $5.4 \mathrm{~cm} / \mathrm{yr}$ (DeMets et al. 1990). Nearly $33 \%$ of the convergence is absorbed by compressional deformation (Molnar and Lyon-Caen 1989; Bilham et al. 1997) and the remaining $\sim 67 \%$ is distributed in a large area spread from Tibet to Mongolia (Molnar and Tapponnier 1977; England and Molnar 1997). Trench parallel and orthogonal partitioning of the oblique convergence resulted the radial slip, alongstrike translation, and extension along this deformation front (McCaffrey and Nabelek 1998). The extension of southern Tibet was accommodated by significant east-west shortening in the western Himalayan syntaxis and eastward motions in southeast Tibet (Butler et al. 1989; Seeber and Pêcher 1998; Larson et al. 1999; Banerjee and Burgmann 2002; Khan et al. 2010). This Late Tertiary deformation in the Himalayas all together sliced the orogeny into five broadly parallel lithotectonic units, separated by mostly north-dipping faults (figure 1 of Godin et al. 2006). The two 
parallel and opposite-sense shear zones, which bounded the Himalayan metamorphic core, termed the Greater Himalayan Sequence (GHS), were more active during the Miocene (Hubbard and Harrison 1989; Searle and Rex 1989; Hodges et al. 1992, 1996). The MCT zone marks the lower boundary of the GHS, juxtaposing the metamorphic core above the underlying Lesser Himalayan sequence. The STD system defines the roof fault of the GHS, marking the contact with the overlying unmetamorphosed Tethyan sedimentary sequence. More southerly structures the MBT and the MFT evolving sequentially (Wobus et al. 2005), separated the Lesser Himalayas to the north from the Sub-Himalayas to the south. The MFT (i.e., surface trace of the MHT) marks the limit between the undeformed sediments lying on the Indian basement and those that have been scraped off and involved in the Siwalik (Sub-Himalayas) fold belt (Cattin et al. 2001).

\section{Data and analysis}

\subsection{Topography}

We have selected 15 profiles (figure 1) at regular separation, orthogonal to the trend of the Himalayas, for reconstruction of the topography (figure 2). Topographic data were compiled from GTOPO 30, global digital elevation model (DEM) with a horizontal grid-spacing of 30 arcsec $(\sim 1 \mathrm{~km})$. We have used tile number E060N40 under the DEM file for illustrating the topography along the different profiles (figure 2) and crustal discontinuities (figure 3). Relative variation of topography was further assessed through estimation of average elevation over $1^{\circ}$ longitude interval with a linear moving window of $0.5^{\circ}$ (overlapping line) along the discontinuities. The moving window has been considered for comprehensive analysis, and maintaining the inherent segment-to-segment continuity of the data points. The dimension of the linear window is selected for incorporating reasonable data points representing the elevation at the mid-point of each $1^{\circ}$ linear segment to understand the $\mathrm{E}-\mathrm{W}$ as well as $\mathrm{N}-\mathrm{S}$ variations of deformation of the arcuate Himalayan segment.

Along $\mathrm{S}$ to $\mathrm{N}$ profile, a sharp rise in elevation in the east, and a relatively gradual rise in average elevation past the MCT towards the central and western parts of the study area are noted (figure 2). Wider irregular topography is also noted between MCT and MBT towards the west and central parts (profiles 3-9, figure 2). Instead, a relatively flat topography is noted beyond MCT towards east. These observations possibly account for more arcparallel erosion rate towards west and increase in landmass transportation towards east. The topography along MFT between Himachal and Darjeeling Himalayas is relatively uniform (figure 3). A small increase in average elevation along MBT, and a sharp rise along MCT towards east might be accounting for anomalous imbalances in mass distribution all along this zone. Guillot et al. (1999) and Finlayson et al. (2002) advocated a differential denudation along the MCT hanging wall from east to west along the Himalayas. The variable denudation was either caused by (a) an eastward increase in slip along the MCT due to counter-clockwise rotation of India with respect to Asia during IndoAsian collision or (b) an eastward change in the dip angle of the subducting Indian plate or (c) an eastward increase in the magnitude of exhumation due to regional variation of climatic conditions or a combination of these factors. An oscillatory variation of topography existing along the MCT is further continued towards south, and decreases significantly near MFT. West to east increase in average elevation along MCT, STD and ITS, decreases sharply past $\sim 80^{\circ} \mathrm{E}$, and becomes minimum at $\sim 82.5^{\circ} \mathrm{E}$. It further increases sharply and almost gets saturated along STD beyond $84^{\circ} \mathrm{E}$. Instead, the average elevation along $\mathrm{MCT}$ beyond $84^{\circ} \mathrm{E}$ increases sharply. It is also clear that the seismicity along this arcuate belt is not distributed evenly; rather it is concentrated in some specific blocks as illustrated in figures 3 and 4 . It is also interesting to note that the maximum concentration of seismicity is apparently associated with areas of higher elevation along MCT. These typical features are either related with variable degree of southward transportation of Asian landmass over the northward underthrusted Indian lithosphere or variable erosion/denudation. The local reduction in elevation (local depression, figure 3) between $\sim 80$ and $84^{\circ} \mathrm{E}$ from north to south all through the ITS, STD, and MCT might be caused by eastwest increase in extension near the hinterlands of the Himalayas or trench-orthogonal extrusion of crustal wedges towards the Himalayan topographic front coupled with vertical collapse of the topography. Thus, the mutual interaction between the underthrusted Indian lithosphere and the overthrusted Asian landmass has a definite role behind both the erosion and generation of seismicity.

\subsection{Seismicity}

We have considered 611 earthquake events (magnitude $\mathrm{M}_{\mathrm{W}} \geq 4.0$ ) along the Himalayan arcuate belt between Himachal and Darjeeling, during the period 1902-2012, for detailed investigation of seismicity distributions (figures 4 and 5). The earthquake data were taken from the catalogues 

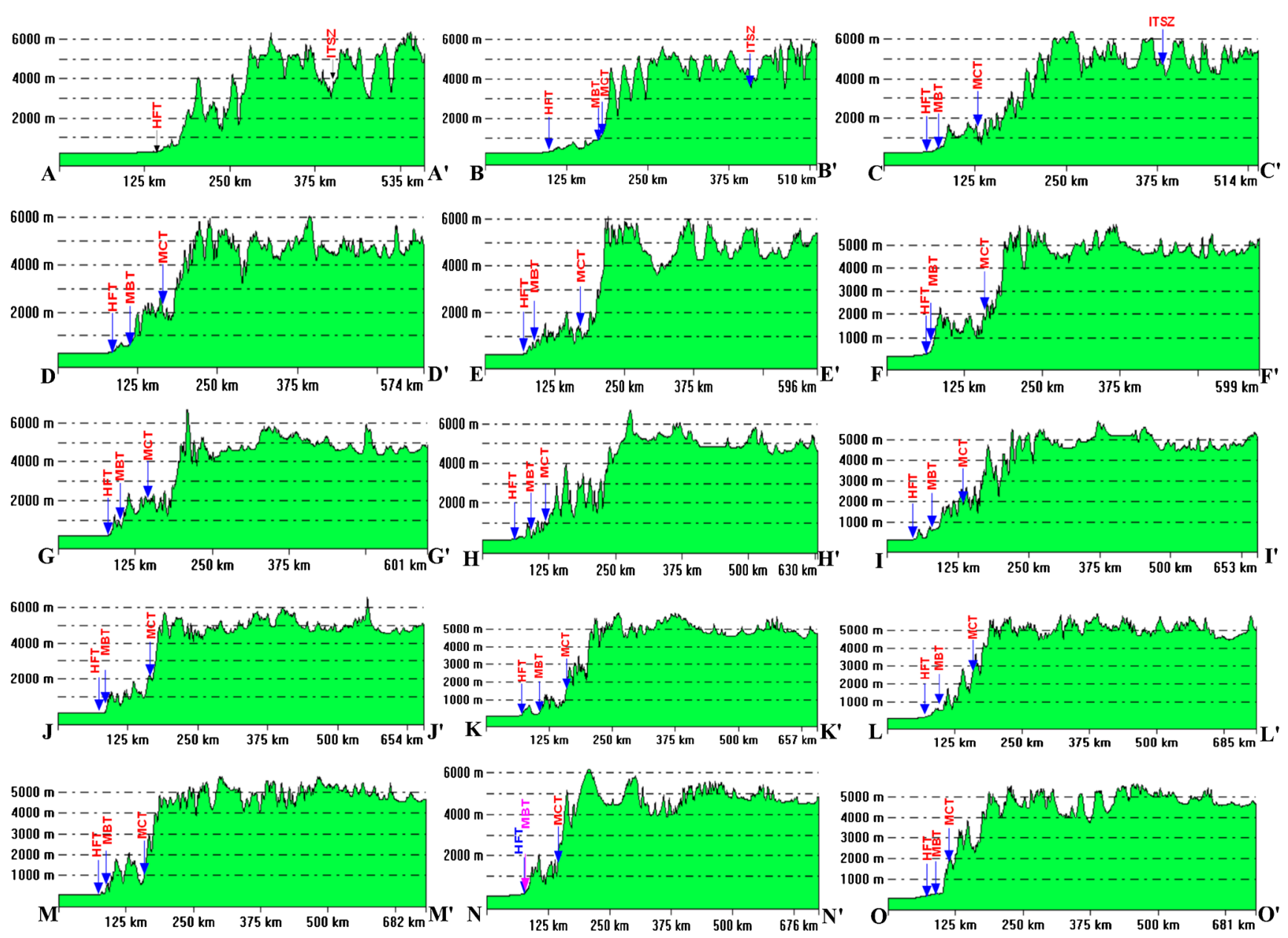

Figure 2. Plots illustrate the reconstructed topography along different traverses from $\mathrm{AA}^{\prime}$ to OO'. The more non-uniform topography towards the western part of the study area may be noted.

of the Indian Society of Earthquake Technology (Bapat et al. 1983), International Seismological Centre, and the US Geological Survey. It was noted that the activities were not uniformly distributed all along the arc; rather confined laterally in some specific blocks surrounding Chamba, Mussourie-Dehradun, near Dharchula and Kalikot, and between Kathmandu and Darjeeling (figure 4). Based on the seismicity distributions, six isolated blocks (block I: 133 events, block II: 132 events, block III: 141 events, block IV: 28 events; block V: 91 events; block VI: 86 events, figure 4) were identified. Figure 5 illustrates the source-distribution of earthquake events, concentrated at depths between $\sim 5$ and $\sim 60 \mathrm{~km}$, though events beyond $60 \mathrm{~km}$ are not rare. Although the variation of seismicity concentration from Himachal to Darjeeling Himalayas is apparently distinct, a significant decrease in concentration is noticed near the central part of the arcuate belt (figures 4 and 5). Although the events are mainly located between the MBT and STD, less seismic activities are also identified to the south of MBT and north of STD, and occasionally to the south of MFT (figures 4 and 6). Six depth-sections of seismicity through the six blocks (figures 4 and 6) indicate that the activities are merely associated with MHT. Further, the geometry of the surface distribution of seismicity towards the western segment of the study area is nearly elliptical with major axis parallel to the strike of the Himalayan orogen, and the strike-parallel ellipticity reduces towards eastern part. Cluster of seismicity is significantly associated with the sharp bending segments of the Indian mid-upper crust (IMUC), Indian lower crust (ILC) or mantle lithosphere. The studies of De (2000), Kayal (2001), Monsalve et al. (2006) and Hazarika et al. (2010) show that the earthquakes are mostly clustered to the north of the MBT without following any particular trend, and a majority of the earthquakes occurred below the plane of detachment, and particularly, the MBT is seismogenic up to the mantle in the Sikkim-Darjeeling Himalayas. 


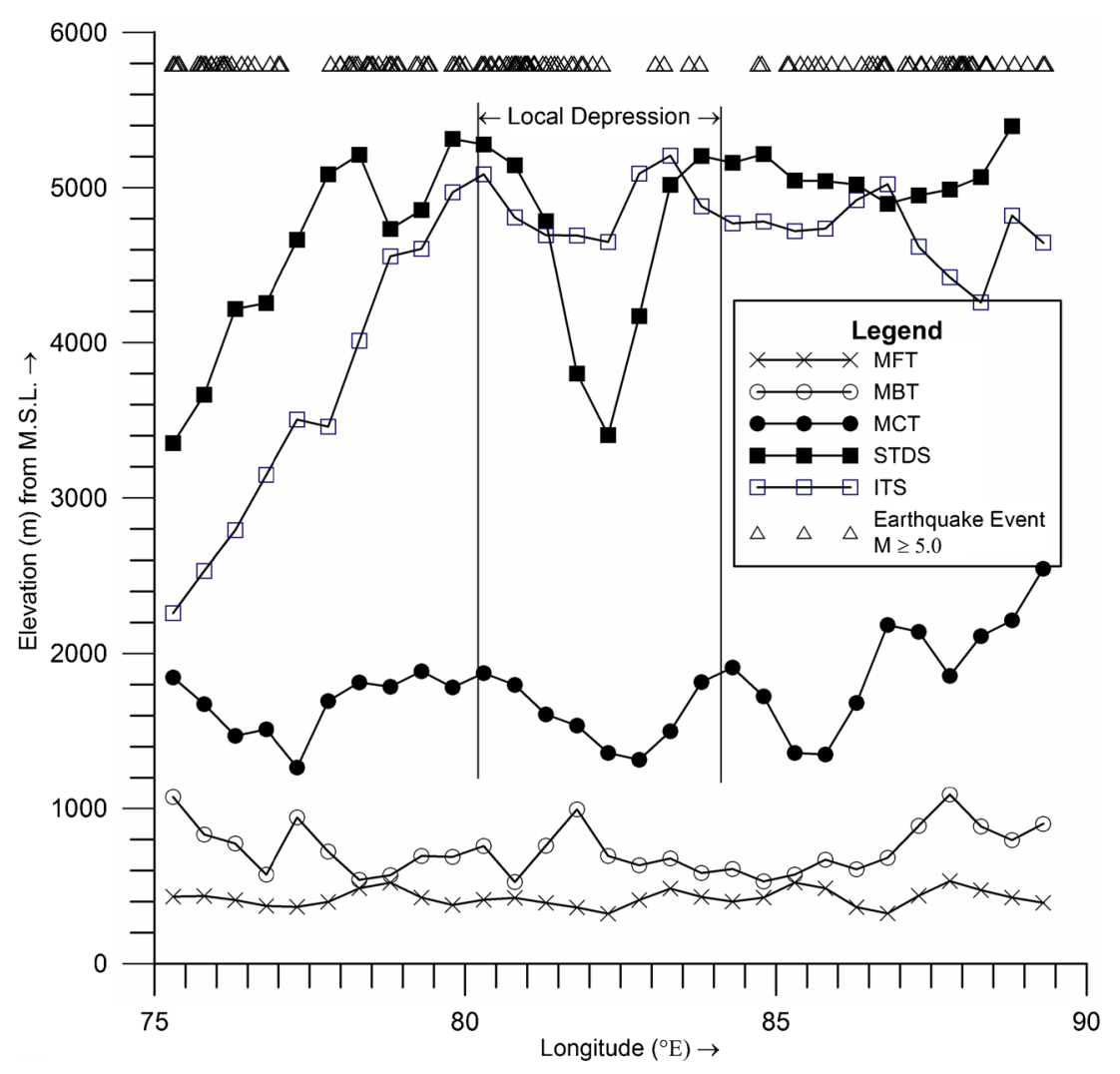

Figure 3. Plots show the variation of topography along different crustal discontinuities (i.e., MFT, MBT, MCT, STD and ITS). The horizontal distributions of open triangles at the top represent the longitudinal variations of earthquake epicenters. The higher concentration of seismicity is associated with average higher topography along MCT. Also note the oscillating nature of topography along MCT. Amplitudes of oscillations sharply decrease towards south.

\subsection{Source processes}

A total of 64 focal mechanisms of earthquakes of magnitude $\mathrm{M}_{\mathrm{W}} \geq 4.7$ (table 1), compiled from the Harvard Centroid Moment Tensor Catalogue and the studies of Tandon (1972), Molnar et al. (1973), Rastogi et al. (1973), Chaudhury et al. (1974), Rastogi (1974, 1976), Tandon and Srivastava (1975), Chandra (1978), Molnar and Tapponnier (1978), Singh and Gupta (1980), Dasgupta et al. (1982) and $\mathrm{Ni}$ and Barazangi (1984), were analyzed for in-depth investigation of geodynamics of the Himalayas. Although the thrust-type movements are apparent in the area between $\sim 75$ and $\sim 82^{\circ} \mathrm{E}$, the thrust, strike-slip, and normal faulting mechanisms are significant towards east (figure 7). Active strike-slip faulting identified towards east can be explained by increasing lateral shearing between the landmass around the MCT. An increasing number of normal faulting earthquakes from south to north past the MCT are quite phenomenal, and particularly confined between $\sim 80$ and $\sim 88^{\circ} \mathrm{E}$. These typical faulting processes are possibly associated with topographic collapse of an overthickened crust (Molnar and Tapponnier 1978; Dewey 1988) coupled with arc-parallel extension in this part of the Himalayas. We also note that the $\mathrm{P}$-axes are nearly orthogonal with the local trend of the orogenic belt for events occurring between $\sim 75$ and $\sim 82{ }^{\circ} \mathrm{E}$ (figure 8 ). Verma and Kumar (1987) reported changes in the orientations of $\mathrm{P}$-axes for all thrust-dominated movements from $\mathrm{N}-\mathrm{S}$ in the part near Darjeeling Himalaya to NE-SW in the western Himalaya. Baranowski et al. (1984), Molnar and Chen (1982), Molnar and Lyon-Caen (1989), Molnar (1990), McCaffrey and Nabelek (1998), and Seeber and Pêcher (1998) found the slip vectors perpendicular to the local trend of the range. A little anomaly in the distributions of $\mathrm{P}$-axes is significant towards east of the orogen.

\subsection{Indian plate obliquity and stress obliquity}

The present study attempts to explore the possible role of topography, plate obliquity (i.e., $\varphi$, angle between the local trench-normal and the plate convergence velocity vector, Jarrard 1986; Ellis and Watkinson 1987; McCaffrey 1992; Liu et al. 1995; Kao et al. 1998; Seeber and Pêcher 1998; Chiao et al. 2001; Soofi and King 2002; Khan and Chakraborty 2005; Khan et al. 2010), stress obliquity (i.e., $\psi$, angle between trench-normal 


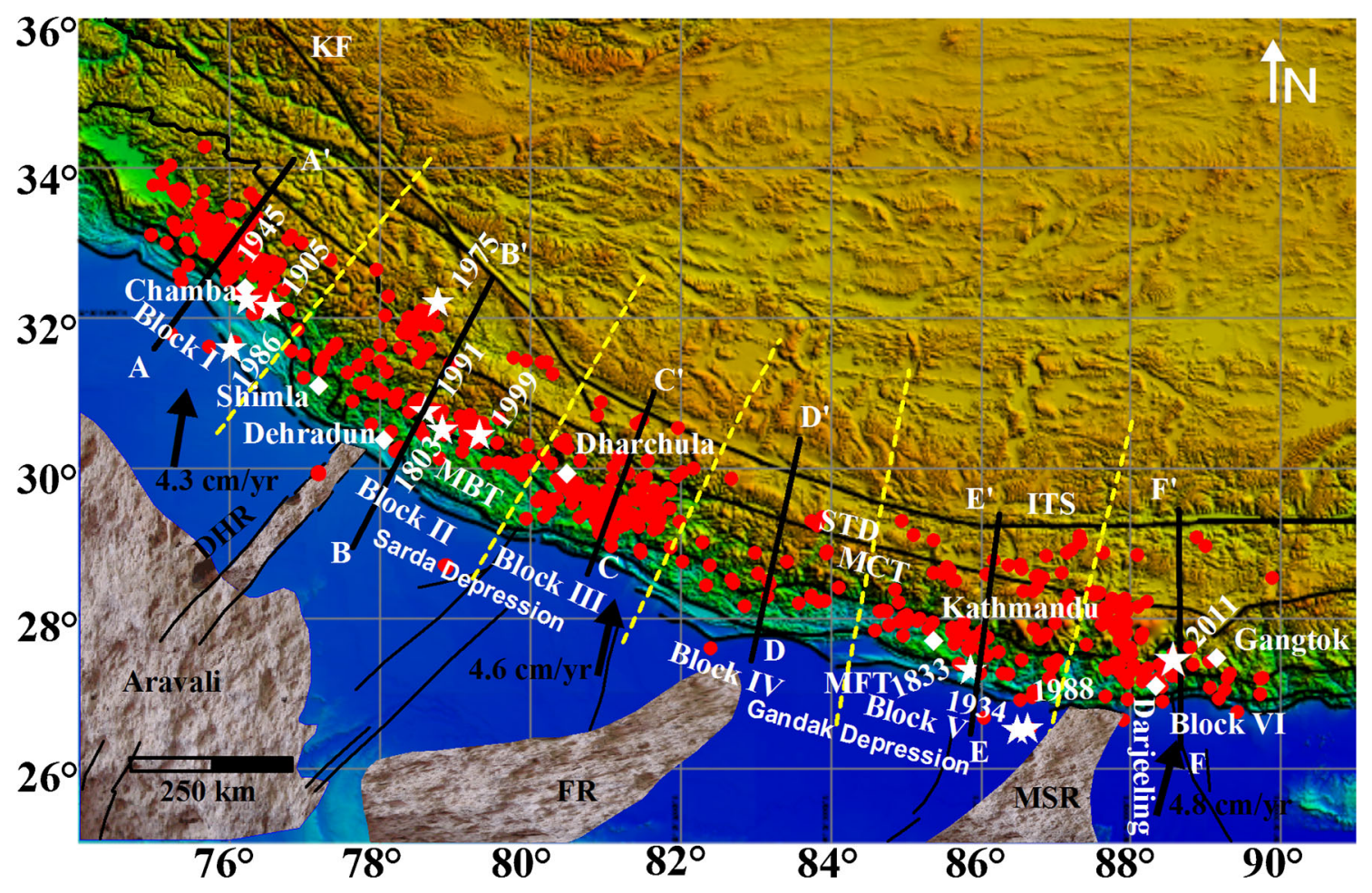

Figure 4. Seismotectonic map of the arcuate Himalayan belt shows the distributions of epicenters of 611 moderate magnitude earthquakes (solid red circles) and 11 historical damaging earthquakes (white solid stars). Four digit numbers adjacent to white solid stars represent the years of occurrences of the damaging earthquakes. Dashed yellow lines demarcate the boundary of seismically active six distinct blocks. Black solid lines along $\mathrm{AA}^{\prime}$ to $\mathrm{FF}^{\prime}$ represent the traverses, orthogonal to the strike of the arcuate Himalayan belt, considered for depth-probing of seismicity in different blocks. Solid black arrows indicate the velocity of convergence of the Indian plate against the Asian plate at respective locations (after DeMets et al. 1994). Abbreviations: KF - Karakoram Fault, others are explained in the caption of figure 1.

and eigenvector of the maximum horizontal compressive stress axis, Khan 2007) behind the incidences of moderate to great earthquakes along the arcuate Himalayan belt. Along oblique convergence margins, the convergence plate velocity vector is generally partitioned into strike-normal and strike-parallel components (Fitch 1972), giving rise to compressional and shear components of strain (Lu and Malavieille 1994; Haq and Davis 1997; Mohanty 2011; Sinha and Mohanty 2012). This may evolve a variety of structures along the collisional boundary following the ratio of compressional to shearing motion (cf. Soofi and King 2002). An assessment of variations of plate and stress obliquities along this arcuate belt reveals a positive correlation between Indian plate obliquity and stress obliquity for 32 earthquake events (figure 9). McCaffrey and Nabelek (1998) and Seeber and Pêcher (1998) have shown that the radial slip, along strike translation, and extension parallel to the deformation front are commonly associated with degree of partitioning of oblique convergence in response to the drag from the downgoing plate, and occur in the hangingwall block of orogenic belts (McCaffrey 1992). The plate-obliquity has minimum value near $85^{\circ} \mathrm{E}$ (figure 9a) and increases both towards east and west. The increase in plate obliquity is associated with increase in shear movement along the strike of the Himalayan orogen, away from the central zone in response to the convergence of the Indian plate below Asia. We advocate that the plateobliquity over the study area possibly controls the compatibility of source dynamics and kinematics with the strike of the trench-axes. Alternatively, a small decrease in degree of coupling between the Asian landmass and the Indian lithosphere along the basal shear plane away from $85^{\circ} \mathrm{E}$ can be inferred. The increasing arc-parallel compression towards eastern and western termini of the Himalayan orogen supports this observation.

A distinct feature of the relationship between longitudinal variations of the plate obliquity is the distribution of 55 data points of seismic events showing gaps at different places (figure 9a). The stress obliquity also shows similar relationship (figure 9b). The correlation between the plate obliquity and stress obliquity (figure 9c) shows a linear relationship, having data distribution of mainly three types: (a) 12 data points have positive intercept on the stress obliquity axis, (b) 32 data points have zero intercept, and (c) 8 data points 

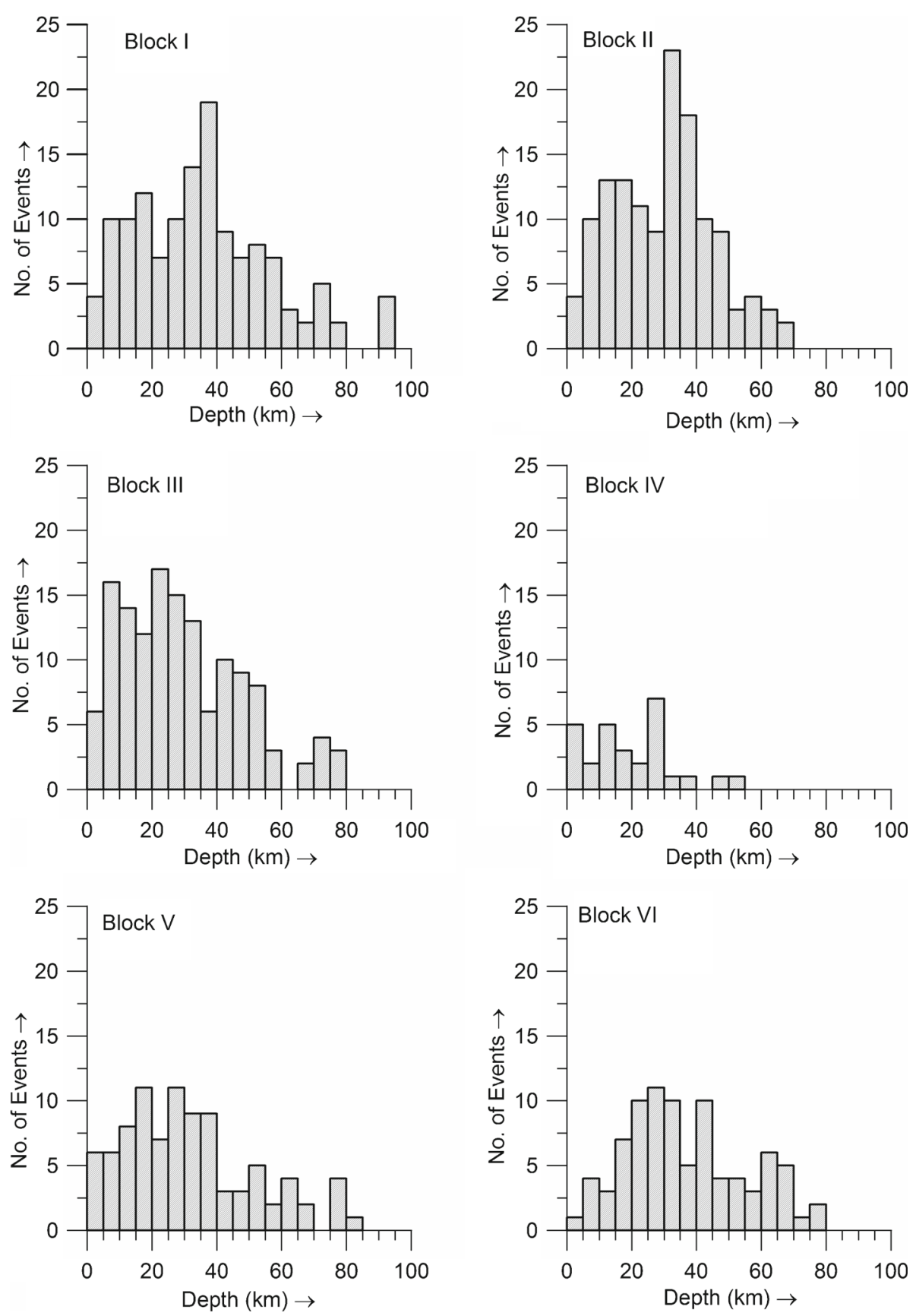

Figure 5. Plots illustrate variations of concentration of earthquake events with respect to their focal depths in six different blocks. Note the occurrences of earthquakes in the Indian lithospheric mantle.

have negative intercept on the stress obliquity axis. The data distribution in the stress obliquity $v s$. longitude show the first type to be in the upper segment of the mean curve, the second type coinciding with the mean curve, and the third type in the lower segment of the mean curve (figure 9b). The first two types of data are interpreted to be the result of pure thrust to transpression stress regime, whereas the third type of data represent the transtension regime. The data cluster at point $\mathrm{C}$ near the central axis of the plate obliquity (figure 9a) has obliquity of $0-5^{\circ}$, and is separated from the adjacent clusters B and D with obliquity between $10^{\circ}$ and $25^{\circ}$. The farthest cluster at $\mathrm{A}$ has obliquity of $33^{\circ}-45^{\circ}$. The cluster at $\mathrm{C}$ is located close to the principal compressive stress axis, representing pure thrust dominated movement. The points in B and D are located close to the orientation of the plane of shear failure predicted by the Mohr-Coulomb theory. The point A is close to the plane of maximum shear stress related to the principal compressive stress at $85^{\circ} \mathrm{E}$. It may be noted that shear failure planes under uniaxial compression make an angle of $\sim 30^{\circ}$ with the maximum 

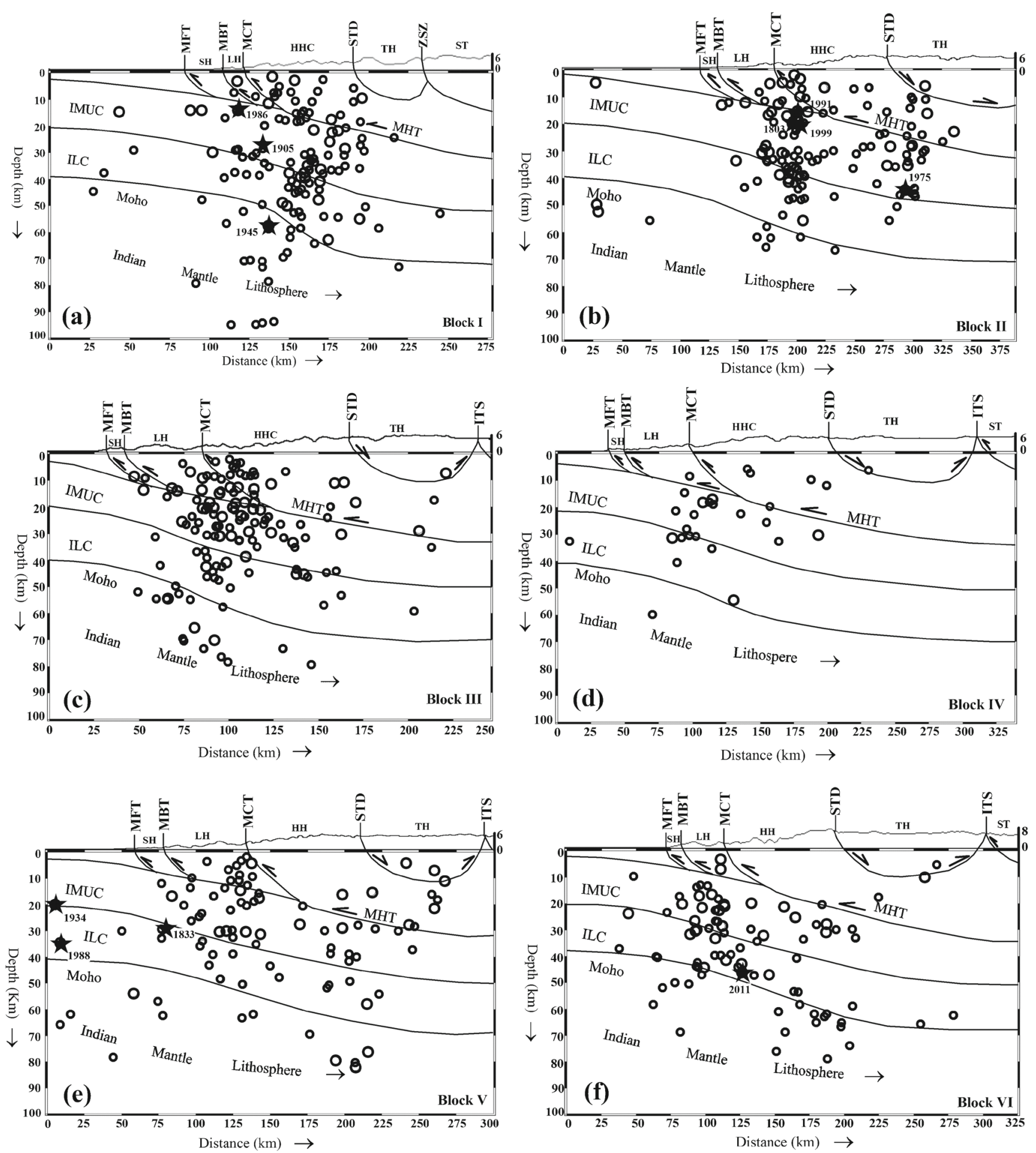

Figure 6. Cartoon illustrating the subduction of the Indian lithosphere beneath the Himalayas (Owens and Zandt 1997; Cattin et al. 2001; Monsalve et al. 2006; Tiwari et al. 2006; Chamoli et al. 2011). Hypocentres of 611 events and 11 damaging earthquakes were projected on six vertical depth-sections along $\mathrm{AA}^{\prime}$ to $\mathrm{FF}^{\prime}$. Four digit numbers adjacent to white solid stars represent the years of occurrences of the damaging earthquakes. Note the association of major concentration of seismicity with the sharp bending portion of the Indian mid-upper crust (IMUC), Indian lower crust (ILC) and Indian mantle lithosphere between MBT and STD. Abbreviations: SH - Siwalik Himalaya, LH - Lower Himalaya, HH - Higher Himalaya, TH - Tethys Himalaya, MHT - Main Himalayan Thrust, ST - Southern Tibet.

principal stress axis (figure 10a). The angle in the present analysis shows a value lower than the predicted model. This can be explained by a deformation model in which the maximum principal stress is compressive and the minimum principal stress is extensional in nature (figure 10b). In 
Table 1. Hypocentral and source parameters of moderate to large magnitude earthquakes in the Himalayas.

\begin{tabular}{|c|c|c|c|c|c|c|c|c|}
\hline \multirow[b]{2}{*}{ Date } & \multirow{2}{*}{$\begin{array}{l}\text { Latitude } \\
\left({ }^{\circ} \mathrm{N}\right)\end{array}$} & \multirow{2}{*}{$\begin{array}{l}\text { Longitude } \\
\left({ }^{\circ} \mathrm{E}\right)\end{array}$} & \multirow{2}{*}{$\begin{array}{l}\text { Depth } \\
(\mathrm{km})\end{array}$} & \multirow[b]{2}{*}{ Magnitude } & \multicolumn{3}{|c|}{ Fault plane 1} & \multirow{2}{*}{$\begin{array}{l}\text { Source } \\
\text { of data }\end{array}$} \\
\hline & & & & & $\overline{\text { Dip }}$ & Strike & $\overline{\text { Rake }}$ & \\
\hline $20 / 05 / 1979$ & 29.58 & 80.32 & 15 & 5.8 & 7 & 274 & 79 & 1 \\
\hline $22 / 06 / 1980$ & 30.1 & 81.59 & 15 & 5.1 & 36 & 28 & -50 & 1 \\
\hline $29 / 07 / 1980$ & 28.96 & 81.11 & 10 & 5.5 & 25 & 278 & 90 & 1 \\
\hline $29 / 07 / 1980$ & 29.42 & 80.95 & 22.3 & 6.5 & 21 & 290 & 92 & 1 \\
\hline $23 / 08 / 1980$ & 32.59 & 75.37 & 15 & 5.5 & 10 & 293 & 63 & 1 \\
\hline $23 / 08 / 1980$ & 32.49 & 75.4 & 15 & 5.5 & 12 & 298 & 82 & 1 \\
\hline $19 / 11 / 1980$ & 27.42 & 89.05 & 44.1 & 6.2 & 51 & 209 & -2 & 1 \\
\hline $10 / 01 / 1986$ & 28.6 & 87.09 & 81.4 & 5.1 & 46 & 140 & -163 & 1 \\
\hline $26 / 04 / 1986$ & 31.59 & 76.06 & 15 & 5.5 & 19 & 299 & 57 & 1 \\
\hline $16 / 07 / 1986$ & 30.48 & 78.19 & 15 & 5.4 & 17 & 278 & 37 & 1 \\
\hline 09/08/1987 & 29.3 & 83.77 & 34 & 5.6 & 43 & 81 & -10 & 1 \\
\hline $20 / 08 / 1988$ & 26.52 & 86.64 & 34.7 & 6.8 & 23 & 230 & 3 & 1 \\
\hline $29 / 10 / 1988$ & 27.39 & 85.73 & 18 & 5.2 & 30 & 309 & -70 & 1 \\
\hline $19 / 10 / 1991$ & 30.22 & 78.24 & 15 & 6.8 & 14 & 317 & 114 & 1 \\
\hline 20/03/1993 & 28.87 & 87.64 & 15 & 6.2 & 46 & 161 & -121 & 1 \\
\hline 05/01/1997 & 29.43 & 80.29 & 15 & 5.5 & 19 & 279 & 68 & 1 \\
\hline 28/03/1999 & 30.38 & 79.21 & 15 & 6.5 & 7 & 280 & 75 & 1 \\
\hline $28 / 09 / 2001$ & 33.0 & 75.46 & 40.5 & 4.9 & 32 & 323 & 105 & 1 \\
\hline $27 / 11 / 2001$ & 29.61 & 81.75 & 15 & 5.5 & 4 & 257 & 63 & 1 \\
\hline $27 / 11 / 2001$ & 28.91 & 81.49 & 15 & 5.4 & 28 & 280 & 73 & 1 \\
\hline $27 / 01 / 2002$ & 33.32 & 75.91 & 28.8 & 5.2 & 20 & 225 & -11 & 1 \\
\hline 04/06/2002 & 30.13 & 81.25 & 15 & 5.6 & 49 & 159 & -130 & 1 \\
\hline $26 / 03 / 2005$ & 28.08 & 87.95 & 69.6 & 4.7 & 62 & 109 & 179 & 1 \\
\hline $31 / 10 / 2005$ & 28.38 & 84.88 & 22.5 & 4.7 & 42 & 120 & 97 & 1 \\
\hline $31 / 10 / 2005$ & 29.39 & 81.28 & 47.0 & 4.7 & 52 & 8 & 176 & 1 \\
\hline $14 / 12 / 2005$ & 30.12 & 78.83 & 34.2 & 5.1 & 23 & 293 & 86 & 1 \\
\hline $01 / 02 / 2006$ & 30.06 & 80.31 & 30.7 & 4.7 & 54 & 156 & -141 & 1 \\
\hline $03 / 02 / 2006$ & 26.94 & 86.7 & 30.9 & 4.7 & 30 & 279 & 91 & 1 \\
\hline $14 / 02 / 2006$ & 27.22 & 88.64 & 19.2 & 5.3 & 27 & 287 & 126 & 1 \\
\hline $20 / 05 / 2007$ & 27.23 & 88.56 & 13.6 & 4.9 & 58 & 204 & -4 & 1 \\
\hline $07 / 11 / 2009$ & 29.31 & 86.28 & 18.8 & 5.5 & 43 & 178 & -91 & 1 \\
\hline $26 / 02 / 2010$ & 28.41 & 86.77 & 84.5 & 5.1 & 69 & 12 & -16 & 1 \\
\hline 06/07/2010 & 29.55 & 80.33 & 14.1 & 5 & 25 & 318 & 140 & 1 \\
\hline 04/04/2011 & 29.37 & 80.69 & 22.9 & 5.4 & 31 & 321 & 125 & 1 \\
\hline 04/04/2011 & 29.43 & 80.71 & 18.8 & 5.4 & 30 & 318 & 128 & 1 \\
\hline $18 / 09 / 2011$ & 27.44 & 88.35 & 46 & 6.9 & 72 & 216 & -12 & 1 \\
\hline $20 / 02 / 1967$ & 33.7 & 75.3 & 18 & 5.6 & 45 & 317 & 91 & 2 \\
\hline $16 / 01 / 1973$ & 33.2 & 75.7 & 42 & 5.1 & 42 & 262 & 46 & 2 \\
\hline $26 / 09 / 1964$ & 30.1 & 80.7 & 50 & 6.2 & 18 & 301 & 97 & 2 \\
\hline $27 / 06 / 1966$ & 29.7 & 80.9 & 37 & 6.1 & 28 & 313 & 106 & 2 \\
\hline $12 / 01 / 1965$ & 27.6 & 88.0 & 23 & 6.1 & 12 & 271 & 90 & 2 \\
\hline $27 / 03 / 1964$ & 27.2 & 89.3 & 32 & 6.3 & 19 & 76 & 90 & 2 \\
\hline $05 / 11 / 1968$ & 32.3 & 76.5 & 33 & 4.9 & 24 & 325 & 74 & 2 \\
\hline $22 / 06 / 1969$ & 30.6 & 79.4 & 19 & 5.4 & 18 & 154 & 106 & 2 \\
\hline $26 / 09 / 1964$ & 30.1 & 80.7 & 50 & 6.2 & 60 & 130 & 90 & 2 \\
\hline $20 / 02 / 1967$ & 33.63 & 75.33 & 18 & 5.6 & 65 & 258 & 59 & 2 \\
\hline $12 / 01 / 1965$ & 27.6 & 88 & 23 & 6.1 & 2 & 279 & 90 & 2 \\
\hline $16 / 01 / 1974$ & 33.2 & 75.7 & 42 & 5.5 & 56 & 209 & 121 & 3 \\
\hline $15 / 01 / 1934$ & 26.5 & 86.5 & 20 & 8.4 & 71 & 334 & 114 & 4 \\
\hline $11 / 12 / 1975$ & 33 & 76.17 & 2 & 5 & 74 & 166 & 90 & 5 \\
\hline 01/01/1976 & 32.97 & 76.12 & 40 & 5.3 & 56 & 150 & 86 & 5 \\
\hline $14 / 06 / 1978$ & 32.24 & 76.16 & 7 & 5 & 72 & 168 & 90 & 5 \\
\hline $31 / 01 / 1975$ & 28.1 & 84.72 & 33 & 5.4 & 80 & 303 & -155 & 6 \\
\hline
\end{tabular}


Table 1. (contd)

\begin{tabular}{|c|c|c|c|c|c|c|c|c|}
\hline \multirow[b]{2}{*}{ Date } & \multirow{2}{*}{$\begin{array}{l}\text { Latitude } \\
\qquad\left({ }^{\circ} \mathrm{N}\right)\end{array}$} & \multirow{2}{*}{$\begin{array}{l}\text { Longitude } \\
\left({ }^{\circ} \mathrm{E}\right)\end{array}$} & \multirow{2}{*}{$\begin{array}{c}\text { Depth } \\
(\mathrm{km})\end{array}$} & \multirow[b]{2}{*}{ Magnitude } & \multicolumn{3}{|c|}{ Fault plane 1} & \multirow{2}{*}{$\begin{array}{l}\text { Source } \\
\text { of data }\end{array}$} \\
\hline & & & & & $\overline{\text { Dip }}$ & Strike & Rake & \\
\hline $16 / 12 / 1966$ & 29.7 & 80.7 & 15 & 5.8 & 39 & 280 & 90 & 7 \\
\hline $16 / 12 / 1966$ & 29.62 & 80.79 & 15 & 5.8 & 24 & 280 & 90 & 7 \\
\hline $12 / 01 / 1965$ & 27.4 & 87.84 & 23 & 6.1 & 75 & 90 & 90 & 7 \\
\hline $24 / 03 / 1974$ & 27.73 & 86.11 & 33 & 5.7 & 88 & 97 & 90 & 8 \\
\hline 19/06/1979 & 26.29 & 87.57 & 24 & 5 & 34 & 179 & 350 & 9 \\
\hline $21 / 02 / 1967$ & 33.7 & 75.4 & 41 & 5.1 & 30 & 280 & 90 & 10 \\
\hline $01 / 06 / 1965$ & 28.5 & 83.2 & 20 & 5.3 & 40 & 267 & 61 & 10 \\
\hline $20 / 02 / 1967$ & 33.6 & 75.4 & 25 & 5.1 & 57 & 156 & 93 & 10 \\
\hline $24 / 10 / 1973$ & 33.1 & 75.9 & 33 & 5.4 & 36 & 168 & 75 & 11 \\
\hline $26 / 02 / 1970$ & 27.6 & 85.7 & 96 & 5 & 76 & 287 & -140 & 11 \\
\hline $28 / 12 / 1958$ & 30 & 79.8 & 30 & 6.2 & 54 & 102 & 90 & 11 \\
\hline
\end{tabular}

Sources: 1. Harvard Centroid Moment Tensor Catalogue, 2. Chandra (1978), 3. Chaudhury et al. (1974), 4. Singh and Gupta (1980), 5. Dasgupta et al. (1982), 6. Molnar et al. (1973), 7. Molnar and Tapponnier (1978), 8. Ni and Barazangi (1984), 9. Rastogi et al. (1973), Rastogi (1974, 1976), 10. Tandon (1972), 11. Tandon and Srivastava (1975).

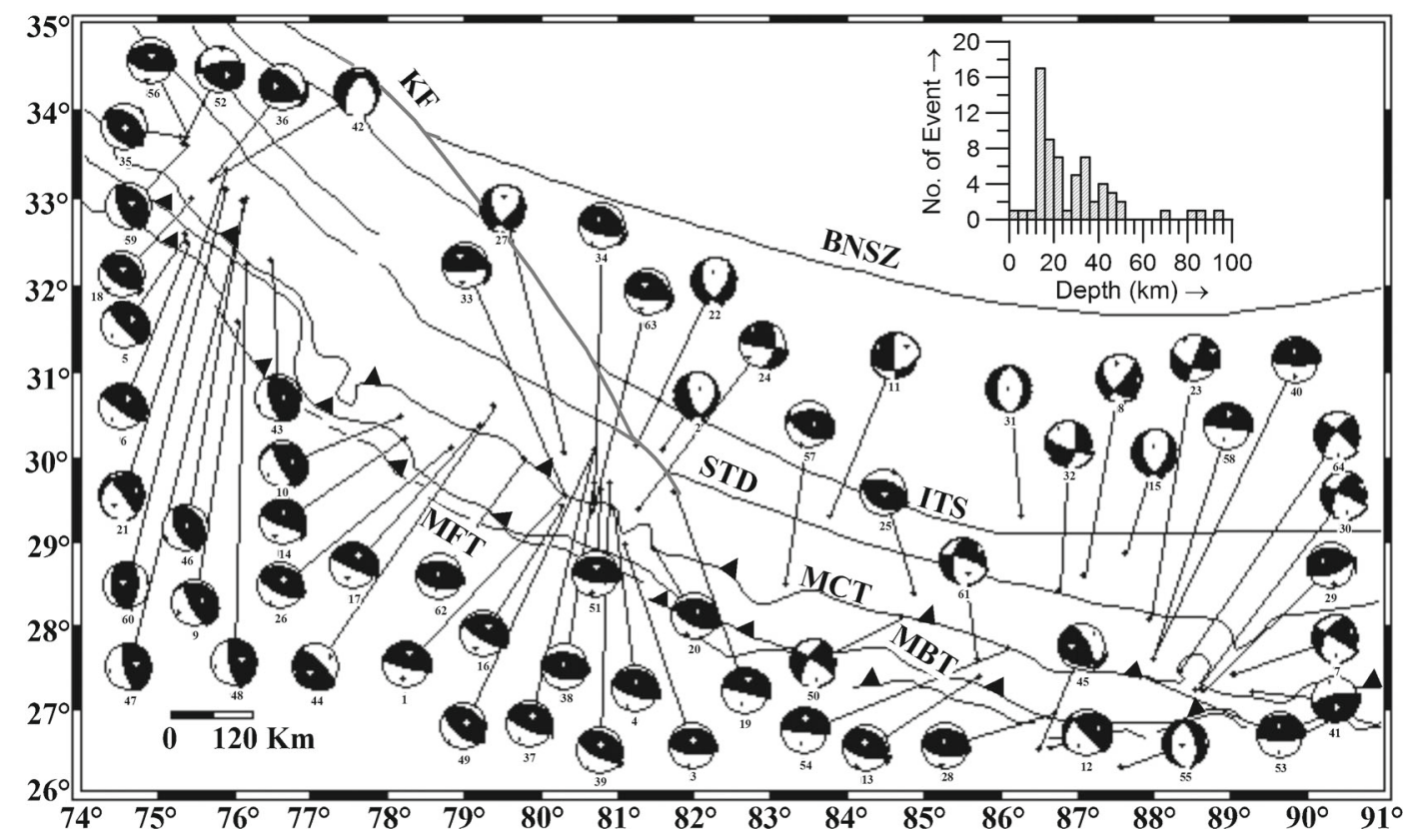

Figure 7. Map explains the subsurface geological processes through beach balls of 64 moderate to large magnitude earthquakes. Top histogram plot indicates the focal-depth distributions of the 64 events. Note the operative thrust dominated movements towards the central and western parts of the study area.

such a deformation scenario, a set of extensional fractures develops parallel to the maximum principal compression axis. Such fractures evolve into normal faults because of extension perpendicular to the fracture plane. A regional E-W extension observed in the southern Tibetan plateau and the transtension regime mentioned earlier are possibly related to this process. This aspect of extensional stress and development of normal faults in the Himalayas is discussed in the next section. The variation of obliquity also controls the development of transpression and transtension domains (figure 10c, d). The partitioning of principal stress $\left(\sigma_{1}\right)$ into normal component $\left(\sigma_{\mathrm{N}}\right)$ and shear component $\left(\sigma_{\mathrm{S}}\right)$ along the plate margin results in development of thrust dominated movement with strike slip (i.e., transpression) in a dominant portion of the plate, but certain segments oblique to the major part give rise to transpression (figure 10c), or transtension (figure 10d) (see also Mohanty 2011; Sinha and Mohanty 2012 for intraplate earthquakes). 


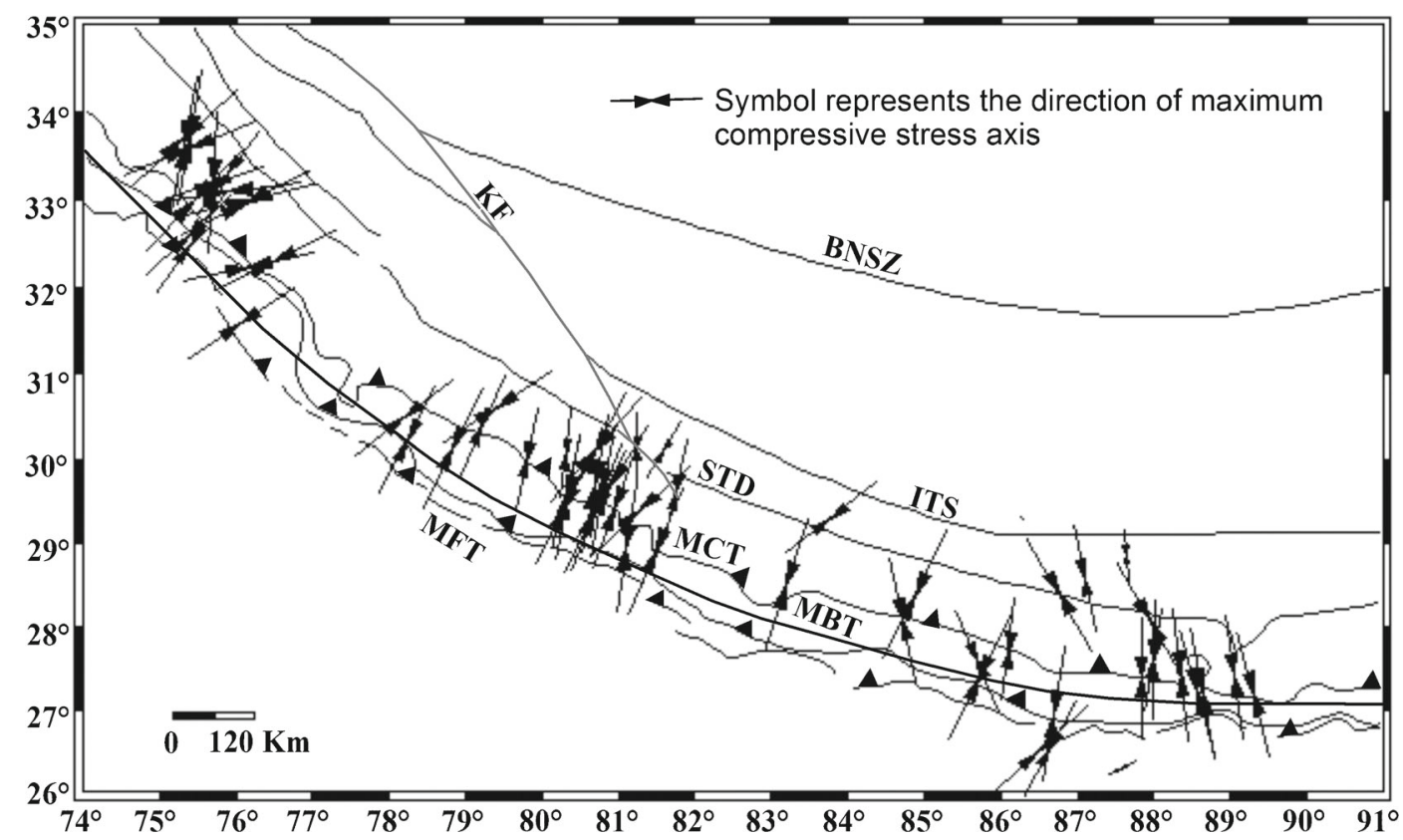

Figure 8. Map shows the regime of maximum horizontal compression operative in different parts of the arcuate Himalayan belt. The lengths of stress directions are related to the plunge of the axes.

\section{Discussion}

Renewed convergence of the Indian plate and subsequent shear traction along the Chaman and Sagaing faults at the western and eastern ends (Patriat and Achache 1984; Yin 2006) presumably caused east-west compression, and created undulation in the Himalayan foreland. Levchenko (1989) reported that the widespread unconformity near the Late Miocene-Pliocene boundary was associated with short pulse of tectonic deformation of the Indian lithosphere, and the occurrences of major tectonic events in the collision between Indian and Asia (Weissel et al. 1980). The evenly spaced down- and upwarping near the foothills of the Himalayas (Sastri et al. 1971; Rao 1973; Valdiya 1976; Dasgupta et al. 1987; Gahalaut and Kundu 2012) possibly took place during this time. The entire Late Miocene deformation processes coupled with the Indian plate obliquity (Fitch 1972; McCaffrey 1991; McCaffrey and Nabelek 1998; Seeber and Pêcher 1998; Khan 2005; Khan and Chakraborty 2005; Ansari and Khan 2014) resulted the spatiotemporal variation of coupling along its convergent margin. Positive correlation between blocks of concentrated seismicity and higher elevation along MCT (figure 3) with the areas of northward-extended Gandak and Sarda depressions possibly indicates the active deformation of the descending lithosphere. Instead, the penetrating ridges (Monghyr-Saharsa, Faizabad,
Delhi-Hardwar), were likely located around the gaps of seismicity and lower topography along MCT (figure 3) in the Himalayan foothills, possibly prohibiting the occurrences of earthquakes. Similar type of episode/quiescence was also observed elsewhere by Kelleher and McCann (1976).

McCaffrey (1992) and Liu et al. (1995) found a positive correlation between the plate obliquity and slip obliquity. The slope in plot of plate obliquity vs. slip obliquity was computed to be either 1.0 or less than one. Liu et al. (1995) suggested that the slope value of $<1.0$ is linked with increased slab pull effects along different subduction margins. Although we find a positive correlation between plate $(\phi)$ and stress obliquity $(\psi)$ as $\psi=1.30 \phi+0.28$ and $\psi=1.15 \phi+27.66$ for 32 and 12 moderate magnitude earthquake events, the values of the slopes in either cases are estimated to be more than one (figure 9c). This observation thrives towards increased downdip resistance or enhanced coupling of the descending Indian lithosphere with the overthrusted landmass at different locations (Liu et al. 1995). This may be noted here that the operative stress fields in Indian lithosphere (Cloetingh and Wortel 1986; Richardson 1992; Sandiford et al. 1995) arise by collisional resistance along the Himalayan orogen. Further, the earthquake focal mechanisms in the continental interior of the Indian plate accounts for high resistance at its northern margin (Chandra 1977; Sandiford et al. 1995; Sinha et al. 2013). Besides, 

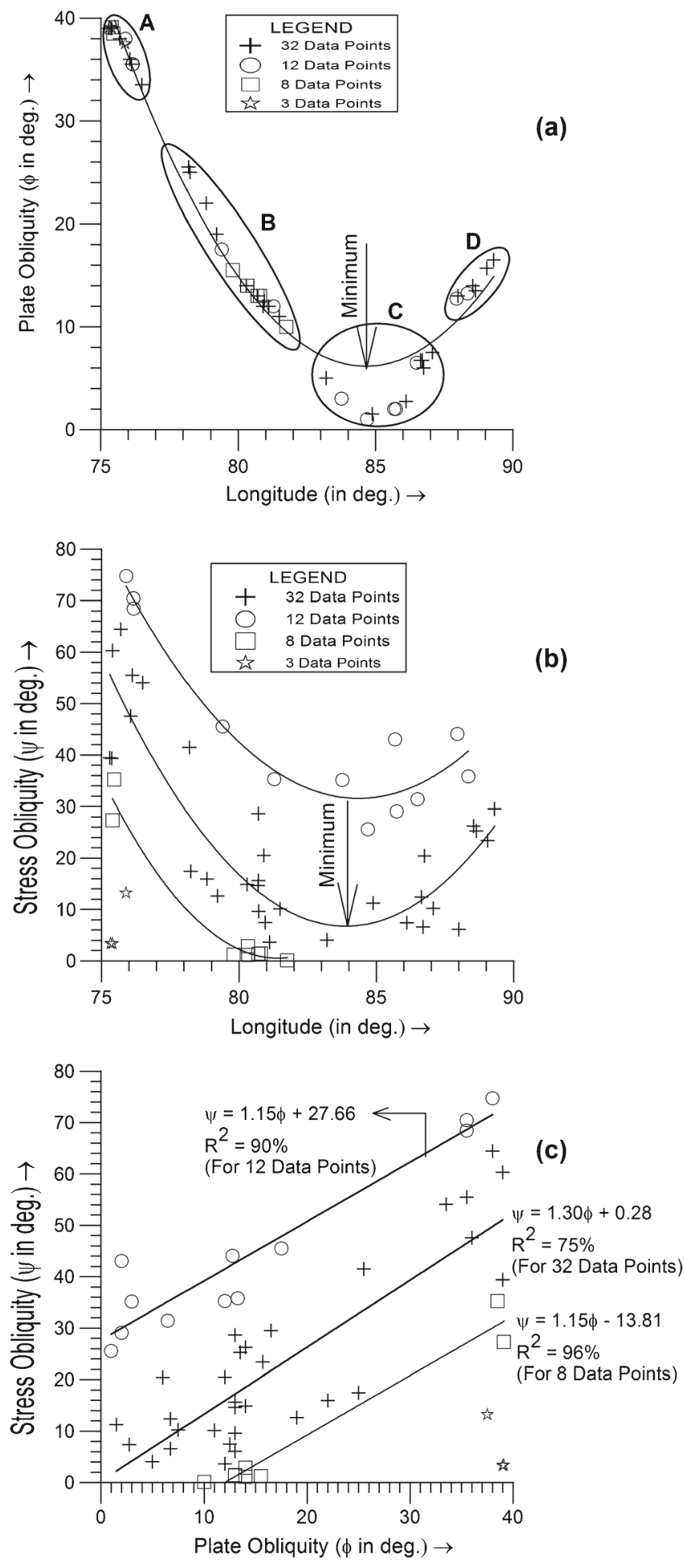

Figure 9. Plots illustrate the along-strike relative comparison between Indian plate obliquity and stress obliquity. (a) Represents the variations of plate obliquity, and (b) stress obliquity against their respective longitude locations. Note the data-point clusters in B and D associate obliquity between $10^{\circ}$ and $25^{\circ}$, and the farthest cluster at A has obliquity of $33^{\circ}-45^{\circ}$. The cluster at $\mathrm{C}$ is preferably located close to the principal compressive stress axis. Relationship between the plate obliquity and stress obliquity (c) shows a linear positive correlation having data distribution of mainly three types. Three open stars are apparently located as outliers. we document larger value of plate obliquity (i.e., $30^{\circ}$ and $40^{\circ}$ ) for more than $20 \%$ events (figure $9 \mathrm{c}$ ), and the intercept between 0.28 and 27.66 are dissimilar to computed values (i.e., zero) of McCaffrey (1992) and Liu et al. (1995). These observations might be accounting for arc-parallel transportation of partially decoupled masses along this margin. Three events likely in the outlier, located at the northwestern part of the study area, show very low value of stress obliquity (figures 7 and 9), which accounts for non-correlation between plate and stress obliquities. The ambiguity in the relation possibly concealed either in the average arc drawn through the mean of MFT, MBT and MCT or local effect. It is appreciated in the literature (Liu et al. 1995) that the along-strike component of the oblique convergence is gradually dissipated by the interplate coupling resistance and the mantle shear as the slab subducts. This accounts for coupled deformation of the overthrusted Asian landmass and underthrusted Indian lithosphere (McCaffrey 1991; Malod and Kemal 1996; McCaffrey et al. 2000; Khan and Chakraborty 2005; Khan et al. 2010).

The depth-distribution of seismicity (figure 6) shows the events are more concentrated around the sharp bending segment of the descending Indian lithosphere. It was also observed elsewhere in many convergence margins that the portion of sharp bending of the subducting lithosphere is the most active zone of seismic slip accumulation (Stern 2002; Khan and Chakraborty 2009; Khan 2011; Khan et al. 2012). Conrad and Hager (1999) also estimated that $\sim 60 \%$ of energy dissipation occurs through the bending (flexing zone) of the subducting slab. It is also postulated that the maximum bending stress of the descending oceanic lithosphere at the subduction margins is about an order of magnitude larger than the maximum strength of the oceanic lithosphere (Kohlstedt et al. 1996; Conrad and Hager 1999), only 10\% of the elastic bending stress is supported without deformation, and the remaining stress is relieved in the form of seismicity by fracturing of rocks (e.g., Turcotte and Schubert 1982). We propose that the bending segment of the descending Indian lithosphere beneath Asia along the Himalayan margin is seismically active. Incidences of nine damaging earthquakes (e.g., 1803 Garhwal, 1833 Nepal-Bihar, 1905 Kangra, 1945 Chamba, 1975 Kinnaur, 1986 Dharmasala, 1991 Uttarkashi, 1999 Chamoli, and 2011 Sikkim, figure 5) within the sharp bending portion of the descending Indian lithosphere support this observation. The seismicity continued in the deeper part of the Indian mantle lithosphere (figure 6) is possibly caused by deformation of the overthrusted Asian landmass and the underthrusted whole Indian lithosphere. 


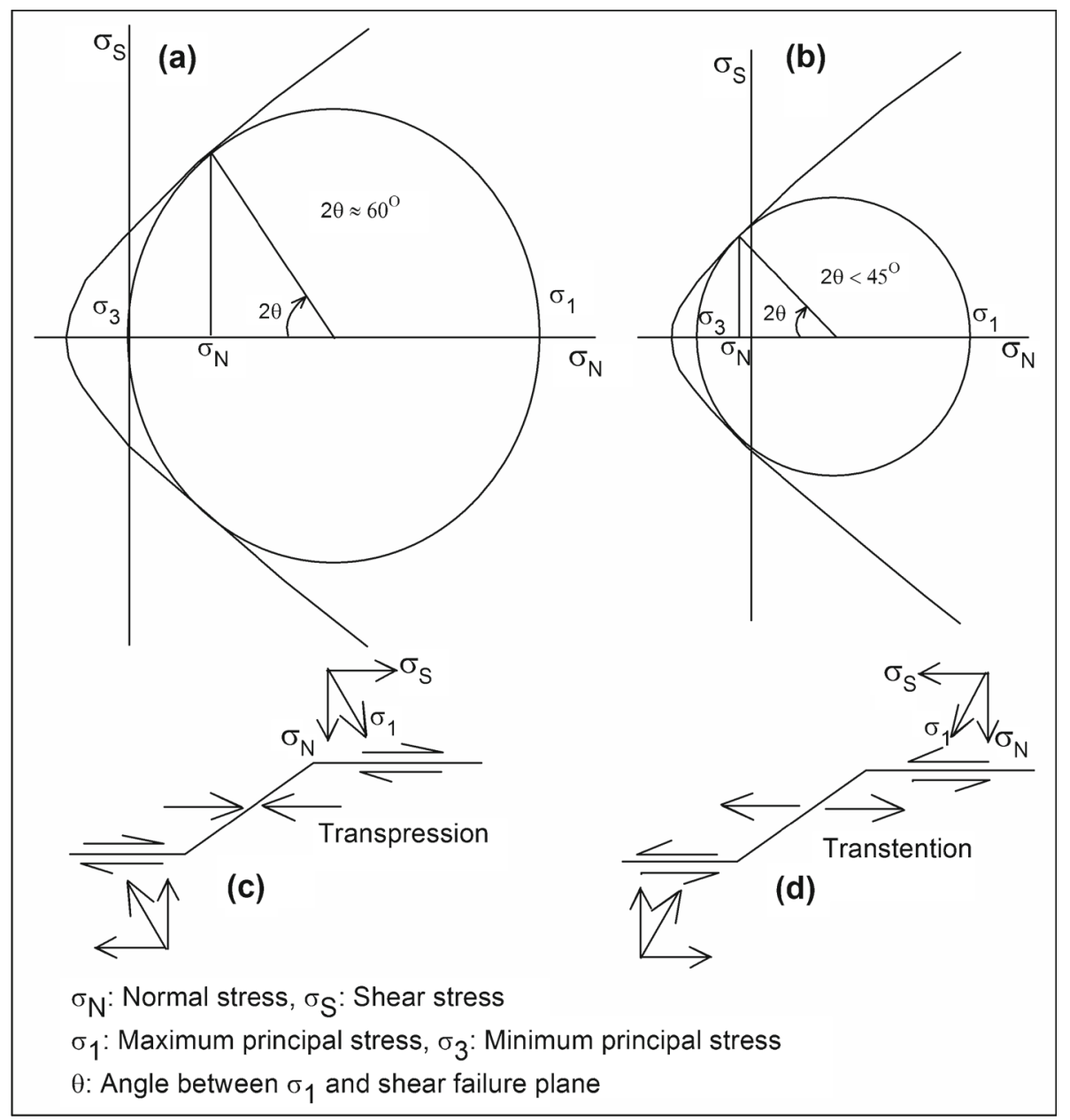

Figure 10. Development of failure planes at different angles $(\theta)$ with respect to the maximum principal compression $\left(\sigma_{1}\right)$, predicted by Mohr-Coulomb failure envelope for uniaxial compression (a) and biaxial ( $\sigma_{1}$ compression and $\sigma_{3}$ extension) deformation (b). Clusters B and D in figure 9 correspond to these failure planes. The slips along these fractures can be antithetic or sympathetic giving rise to transpression (c) or transtension (d), respectively. Combined effects of conditions illustrated in (b) and (d) can explain the development of normal faults in orogenic belts.

\section{Conclusions}

Incidences of moderate to large earthquakes in some specific segments with apparent seismic gaps along the arcuate Himalayan Mountain Range are related to the lateral deformation of the converging Indian lithosphere initiated during Late Miocene-Pliocene period. The convergence of the Indian plate created EW axial compression during its movement along the Chaman shear zone in the west and Sagaing shear zone in the east. This distinct motion creating evenly spaced domal structures in the Himalayan foreland built-up variable degree of decoupling between the overthrusted Asian landmass and underthrusted Indian lithosphere. The segment-specific clustering of seismicity is identified to be the manifestation of this coupling effect. The less active seismic zone or the gaps possibly represent the areas of quiescence of recent episodes of tectonic pulse. The NNE-SSW trending ridges in the Indian plate converging towards the frontal part of the Himalayas are presumably prohibiting the generation of moderate to large earthquakes in the Himalayas. We also advocate that the recurrences of large damaging earthquakes in some specific areas are likely related with anomalous arcparallel compression in the Himalayas. We find a positive correlation between Indian plate obliquity and stress obliquity for reasonable number of seismic events. Slopes of correlations for three isolated dataset were estimated to be more than one and the ordinate intercepts vary between -13.81 and 27.66. This supports the view of variable degree of coupling between the two converging plates.

Highest concentration of seismicity around the sharp bent portion of the penetrating Indian mid-upper crust, lower crust and lithospheric mantle, and less seismic activities within the less bent part apparently indicate the bending zone to be the nodal area of stress accumulation. Some of the events, continued into the deeper part of the descending Indian lithospheric mantle, 
are the manifestations of active deformation along the arcuate Himalayan belt. The curved nature of the oroclinal front developed transpression and transtension in certain segments. The former zones develop prevalently along low-angle antithetic shear bends whereas the latter condition is suitable along low-angle sympathetic shear bends (figure 10). The extensional tectonics operative towards the northern part and in southern Tibet might be the effect of combination of oblique subduction, oroclinal bending, and concentrated compression in the central part of the Himalayan arc.

\section{Acknowledgement}

Authors are grateful to the Director, Indian School of Mines, Dhanbad for the financial support to carry out the present work.

\section{References}

Ahnert F 1970 Functional relationships between denudation, relief and uplift in large, mid-latitude drainage basins; Am. J. Sci. 268 243-263.

Ansari M A and Khan P K 2014 Occurrences of damaging earthquakes between the Himachal and Darjeeling Himalayas: Tectonic implications; Acta Geophys., doi: 10.2478/s11600-013-0190-5.

Armijo R, Tapponnier P, Mercier J L and Tonglin H 1986 Quaternary extension in southern Tibet: Field observations and tectonic implications; J. Geophys. Res. 91 $13,803-13,872$.

Avouac J P and Burov E B 1996 Erosion as a driving mechanism of intracontinental mountain growth; J. Geophys. Res. 101 17,747-17,769.

Banerjee P and Burgmann R 2002 Convergence across the northwest Himalaya from GPS measurements; Geophys. Res. Lett. 29(13) 31-34.

Bapat A, Kulkarni R C and Guha S K 1983 Catalogue of earthquakes in India and neighborhood - from historical period up to 1979; Indian Society of Earthquake Technology, Roorkee.

Baranowski J, Armbruster J, Seeber L and Molnar P 1984 Focal depths and fault plane solutions of earthquakes and active tectonics of the Himalaya; J. Geophys. Res. 89 6918-6928.

Beaumont C, Jamieson R A, Nguyen M H and Lee B 2001 Himalayan tectonics explained by extrusion of a low-viscosity crustal channel coupled to focused surface denudation; Nature 414 738-742.

Bendick R and Bilham R 2001 How perfect is the Himalayan Arc? Geol. 29 791-794.

Bilham R, Larson K and Freymueller J 1997 GPS measurements of present-day convergence across the Nepal Himalaya; Nature 386 61-64.

Burchfiel B C and Royden L H 1985 North-south extension within the convergent Himalayan region; Geol. 13 679682.

Burg J P, Leyreloup A, Marchand J and Matte P 1984 Inverted metamorphic zonation and large scale thrusting in the Variscan belt: An example; In: French Massif Central, Variscan tectonics of the North Atlantic region (eds)
Hutton D H W and Sanderson D J , Geol. Soc. London Spec. Publ. 14 47-61.

Butler R W H, Prior D J and Knipe R J 1989 Neotectonics of Nanga Parbat Syntaxis, Pakistan, and crustal stacking in the northwest Himalayas; Earth Planet. Sci. Lett. 94 329-343.

Cattin R and Avouac J P 2000 Modeling mountain building and the seismic cycle in the Himalaya of Nepal; J. Geophys. Res. 105 389-401.

Cattin R, Martelet G, Henry P, Avouac J P, Diament M and Shakya T R 2001 Gravity anomalies, crustal structure and thermo-mechanical support of the Himalaya of central Nepal; Geophys. J. Int. 147 381-392.

Chamoli A, Pandey A K, Dimri V P and Banerjee P 2011 Crustal configuration of the northwest Himalaya based on modeling of gravity data; Pure Appl. Geophys. 168 $827-844$.

Chandra U 1977 Earthquakes of peninsular India - a seismotectonic study; Bull. Seismol. Soc. Am. 67 13871413.

Chandra U 1978 Seismicity, earthquake mechanisms and tectonics along the Himalayan mountain range and vicinity; Phys. Earth Planet. Inter. 16 109-131.

Chaudhury H M, Srivastava H N and Rao J S 1974 Seismotectonic investigations in the Himalayas; Him. Geol. 4 481-491.

Chiao L Y, Kao H, Lallemand S and Liu C S 2001 An alternative interpretation for slip vector residuals of subduction interface earthquakes: A case study in the westernmost Ryukyu slab; Tectonophys. 333 123-134.

Cloetingh S and Wortel R 1986 Stress in the Indo-Australian plate; Tectonophys. 132 49-67.

Conrad C P and Hager B H 1999 Effects of plate bending and fault strength at subduction zones on plate dynamics; J. Geophys. Res. 104(B8) 17,551-17,571.

Copley A, Avouac J P and Royer J Y 2010 IndiaAsia collision and the Cenozoic slowdown of the Indian plate: Implications for the forces driving plate motions; J. Geophys. Res. 115 B03410.

Dasgupta A, Srivastava H N and Basu M S 1982 Source mechanism of earthquakes in Kangra-Chamba region of Himachal Pradesh, India; Bull. Ind. Soc. Earthq. Tech. $19102-116$.

Dasgupta S, Mukhopadhyay M and Nandy D R 1987 Active transverse features in the central portion of the Himalaya; Tectonophys. 136 255-264.

Davis D, Suppe J and Dahlen F A 1983 Mechanics of foldand-thrust belts and accretionary wedges; J. Geophys. Res. 88(B2) 1153-1178.

De R 2000 A microearthquake survey at the MBT zone: Sikkim Himalaya; J. Geophys. 21 1-8.

DeMets C, Gordon R G, Argus D F and Stein S 1990 Current plate motions; Geophys. J. Int. 101 425-478.

DeMets C, Gordon R G, Argus D F and Stein D 1994 Effect of recent revisions to the geomagnetic reversal time scale and estimates of current plate motions; Geophys. Res. Lett. 21 2191-2194.

Deplus C, Diament M, Hébert H, Bertrand G, Dominguez S, Dubois J, Malod J, Patriat P, Pontoise B and Sibilla J J 1998 Direct evidence of active deformation in the eastern Indian oceanic plate; Geol. 26 131-134.

Dewey J F 1988 Extensional collapse of orogens; Tectonics 7 1123-1139.

Diament M, Harjono H, Karta K, Deplus C, Dahrin D, Zen Jr M T, Gerard M, Lassal O, Martin A and Malod J A 1992 Mentawai fault zone off Sumatra: A new key to the geodynamics of western Indonesia; Geol. 20 259-262.

Ellis M and Watkinson A J 1987 Orogen-parallel extension and oblique tectonics: The relation between stretching 
lineations and relative plate motions; Geol. 15 10221026.

Ellis S, Fullsack P and Beaumont C 1995 Oblique convergence of the crust driven by basal forcing: Implications for length-scales of deformation and strain portioning in orogens; Geophys. J. Int. 120 24-44.

England P and McKenzie D 1982 A thin viscous sheet model for continental deformation; Geophys. J. Roy. Astron. Soc. 70 295-321.

England P and Molnar P 1997 The field of crustal velocity in Asia calculated from Quaternary rates of slip on faults; Geophys. J. Int. 130 551-582.

Fielding E, Isacks B, Barazangi M and Duncan C 1994 How flat is Tibet? Geol. 22(2) 163-167.

Finlayson D P, Montgomery D R and Hallet B 2002 Spatial coincidence of rapid inferred erosion with young metamorphic massifs in the Himalayas; Geol. 30 219222.

Fitch T J 1972 Plate convergence, transcurrent faults and internal deformation adjacent to southeast Asia and the western Pacific; J. Geophys. Res. 77 4432-4460.

Gahalaut V K and Kundu B 2012 Possible influence of subduction ridges on the Himalayan arc and on the ruptures of great and major Himalayan earthquakes; Gondwana Res. 21 1080-1088.

Gansser A 1964 Geology of the Himalaya; Intersci. Publ. London, pp. 1-273.

Gapais D, Pecher A, Gilbert E and Ballevre M 1992 Synconvergence spreading of the main central sheet, Ladakh Himalaya; Tectonics 11 1045-1056.

Garzanti E, Critelli S and Ingersoll R 1996 Paleogeographic and paleotectonic evolution of the Himalayan Range as reflected by detrital modes of Tertiary sandstones and modern sands (Indus transect, India and Pakistan); Geol. Soc. Am. Bull. 108 631-642.

Godin L, Grujic D, Law R D and Searle M P 2006 Channel flow, ductile extrusion and exhumation in continental collision zones: An introduction; In: Channel flow, ductile extrusion and exhumation in continental collision zones (eds) Searle R D and Law M P, Geol. Soc. London Spec. Publ. 268 1-23.

Gordon R G, DeMets C and Argus D F 1990 Kinematic constraints on distributed lithospheric deformation in the equatorial Indian Ocean from present motion between the Australian and Indian plates; Tectonics 9 409-422, doi: 10.1029/TC009i003p00409.

Guillot S, Cosca M, Allemand P and Le Fort P 1999 Constraining metamorphism and geochronological evolution along the Himalayan belt; In: Himalayan Tibet: Mountain roots to mountain tops (eds) Macfarlane A, Sorkhabi R B and Quade J, Geol. Soc. Am. Spec. Paper 328 117-128.

Hall R 1997 Cenozoic plate tectonic reconstructions of SE Asia; In: Petroleum geology of southeast Asia (eds) Fraser A J, Matthews S J and Murphy R W, Geol. Soc. London Spec. Publ. 126 11-23.

Haq S S B and Davis D M 1997 Oblique convergence and the lobate mountain belts of western Pakistan; Geol. 25 23-26.

Harris N 2007 Channel flow and the Himalayan-Tibetan orogen: A critical review; J. Geol. Soc. London 164 511-523, doi: 10.1144/0016-76492006-133.

Harrison T M, Copeland P, Kidd W S F and Yin A 1992 Raising Tibet; Sci. 255 1663-1670, doi: 10.1126/ science.255.5052.1663.

Hazarika P, Kumar M R, Srijayanthi G, Raju P S, Rao P N and Srinagesh D 2010 Transverse tectonics in the Sikkim Himalaya: Evidence from seismicity and focal-mechanism data; Bull. Seismol. Soc. Am. 100(4) 1816-1822, doi: $10.1785 / 0120090339$.
Hintersberger E, Thiede R C, Strecker M R and Hacker B R 2010 East-west extension in the NW Indian Himalaya; Geol. Soc. Am. Bull. 122 1499-1515, doi: 10.1130/ B26589.1.

Hodges K V 2000 Tectonics of the Himalayan and southern Tibet from two perspective; Geol. Soc. Am. Bull. 112 324-350.

Hodges K V, Parrish R, Housh T, Lux D, Burchfiel B C, Royden L and Chen Z 1992 Simultaneous Miocene extension and shortening in the Himalayan orogen; Sci. 258 1466-1470.

Hodges K V, Parrish R R and Searle M P 1996 Tectonic evolution of the central Annapurna Range, Nepalese Himalaya; Tectonics 15(6) 1264-1291, doi: 10.1029/ 96TC01791.

Houseman G and England P 1993 Crustal thickening versus lateral expulsion in the India-Asia continental collision; J. Geophys. Res. 98 12,233-12,249.

Hovius N 2000 Macroscale process systems of mountain belt erosion; In: Geomorphology and Global Tectonics (ed.) Summerfield M A (Chichester: John Wiley and Sons Ltd.), pp. 77-105.

Hubbard M S and Harrison T M $1989{ }^{40} \mathrm{Ar} /{ }^{39} \mathrm{Ar}$ age constraints on deformation and metamorphism in the Main Central Thrust zone and in Tibetan Slab, eastern Nepal Himalaya; Tectonics 8 865-880.

Jackson M and Bilham R 1994 Constraints on Himalayan deformation inferred from vertical velocity fields in Nepal and Tibet; J. Geophys. Res. 99(B7) 13897-13912.

Jarrard R D 1986 Relations among subduction parameters; Rev. Geophys. 24 217-284.

Kao H, Shen S J and Ma K F 1998 Transition from oblique subduction to collision: Earthquakes in the southernmost Ryukyu arc-Taiwan region; J. Geophys. Res. 103 7211-7229.

Kayal J R 2001 Microearthquake activity in some parts of the Himalaya and the tectonic model; Tectonophys. 339 331-351.

Kelleher J and McCann W 1976 Buoyant zones, great earthquakes, and unstable boundaries of subduction; J. Geophys. Res. 81 4885-4896.

Khan P K 2004 Recent seismicity trend in India and adjoining regions; J. Ind. Soc. Earthq. Tech., pp. 10-14.

Khan P K 2005 Variation in dip-angle of the Indian plate subducting beneath the Burma plate and its tectonic implications; Int. Geosci. J. 9 227-234.

Khan P K and Chakraborty P P 2005 Two-phase opening of Andaman Sea: A new seismotectonic insight; Earth Planet Sci. Lett. 229 259-271.

Khan P K 2007 Lithospheric deformation under pre- and post-seismic stress fields along the Nicobar-Sumatra subduction margin during 2004 Sumatra mega-event and its tectonic implications; Gondwana Res. 12 468-475.

Khan P K 2011 Role of unbalanced slab resistive force in the 2004 off Sumatra megaearthquake $\left(\mathrm{M}_{\mathrm{w}}>9.0\right)$ event; Int. J. Earth Sci. 100 1749-1758, doi: 10.1007/s00531010-0576-4.

Khan P K and Chakraborty P P 2009 Plate geometry, plate rheology, and their relation to shallow-focus mega-thrust seismicity with special reference to 26 December 2004 Sumatra event; J. Asian Earth Sci. 34 480-491.

Khan P K, Mohanty S and Mohanty M 2010 Geodynamic implications for the 8 October 2005 North Pakistan earthquake; Surv. Geophys. 31 85-106, doi: 10.1007/s10712009-9083-1.

Khan P K, Chakraborty P P, Tarafder G and Mohanty S 2012 Testing the intraplate origin of mega-earthquakes at subduction margins; Geosci. Front. 3 473-481, doi: 10.1016/j.gsf.2011.11.012. 
Kohlstedt D L, Keppler H and Rubie D C 1996 Solubility of water in the $\alpha, \beta$ and $\gamma$ phases of $(\mathrm{Mg}, \mathrm{Fe})_{2} \mathrm{SiO}_{4} ;$ Contrib. Mineral. Petrol. 123 345-357.

Koons P O 1989 The topographic evolution of collision mountain belts: A numerical look in southern Alps, New Zealand; Am. J. Sci. 289 1041-1069.

Larson K, Bürgmann R, Bilham R and Freymueller J T 1999 Kinematics of the India-Eurasia collision zone from GPS measurement; J. Geophys. Res. 104 1077-1093.

Lavé J and Avouac J P 2001 Fluvial incision and tectonic uplift across the Himalayas of central Nepal; J. Geophys. Res. 106(B11) 26,561-26,591.

Leg 116 Shipboard Scientific Party 1987 Collision in the Indian Ocean; Nature 330 519-521.

Levchenko O V 1989 Tectonic aspects of intraplate seismicity in the northeastern Indian Ocean; Tectonophys. 170 $125-139$.

Liu X, McNally K C and Shen Z K 1995 Evidence for a role of the downgoing slab in earthquake slip partitioning at oblique subduction zones; J. Geophys. Res. 100(B8) $15,351-15,372$.

Lu C Y and Malavieille J 1994 Oblique convergence, indentation and rotation tectonics in the Taiwan mountain belt: Insight from experimental modeling; Earth Planet. Sci. Lett. 121 477-494.

Lyon-Caen H and Molnar P 1983 Constraints on the structure of the Himalaya from an analysis of gravity anomalies and a flexural model of the lithosphere; J. Geophys. Res. 88 8171-8192.

Malod J A and Kemal B M 1996 The Sumatra margin: Oblique subduction and lateral displacement of the accretionary prism; In: Tectonic evolution of southeast Asia (eds) Hall R and Blundell D, Geol. Soc. London Spec. Publ. 106 19-28, doi: 10.1144/GSL.SP.1996.106.01.03.

McCaffrey R 1991 Slip vectors and stretching of the Sumatran forearc; Geol. 19(9) 881-884.

McCaffrey R 1992 Oblique plate convergence, slip vectors, and forearc deformation; J. Geophys. Res. 97(B6) 8905-8915.

McCaffrey R and Nabelek J 1998 Role of oblique convergence in the active deformation of the Himalayas and southern Tibet; Geol. 26 691-694.

McCaffrey R, Zwick P C, Bock Y, Prawirodirdjo L, Genrich J F, Stevens C W, Puntodewo S O and Subarya C 2000 Strain partitioning during oblique plate convergence in northern Sumatra: Geodetic and seismologic constraints and numerical modeling; J. Geophys. Res. 105 28,36328,376 .

McKenzie D and Sclater J G 1971 The evolution of the Indian Ocean since the late Cretaceous; Geophys. J. Roy. Astron. Soc. 25 437-528.

Mohanty S 2011 Crustal stress and strain patterns in the Indian plate interior: Implications for the deformation behaviour of a stable continent and its seismicity; Terra Nova 23 407-415, doi: 10.1111/j.1365-3121.2011.01027.x.

Molnar P 1990 A review of the seismicity and the rates of active underthrusting and deformation at the Himalaya; J. Him. Geol. 1(2) 131-154.

Molnar P and Tapponnier P 1975 Cenozoic tectonics of Asia: Effects of a continental collision; Sci. 189 419-426.

Molnar P and Tapponnier P 1977 The relation of the tectonics of eastern China to the India-Eurasia collision: An application of slip line field theory to large-scale continental tectonics; Geol. 5 212-216.

Molnar P and Tapponnier P 1978 Active tectonics of Tibet; J. Geophys. Res. 83 5361-5369.

Molnar P and Chen W P 1982 Seismicity and mountain building; In: Mountain Building Processes (eds)
Briegel U and Hsu K J (New York: Academic Press), pp. $41-57$.

Molnar P and Lyon-Caen H 1989 Fault plane solutions of earthquakes and active tectonics of the Tibetan plateau and its margin; Geophys. J. Int. 99 123153.

Molnar P and England P 1990 Temperatures, heat flux, and frictional stress near major thrust faults; J. Geophys. Res. $954833-4856$.

Molnar P, Fitch T J and Wu F T 1973 Fault plane solutions of shallow earthquakes and contemporary tectonics of Asia; Earth Planet. Sci. Lett. 19(2) 101-112.

Molnar P, England P and Martinod J 1993 Mantle dynamics, the uplift of the Tibetan Plateau, and the Indian monsoon; Rev. Geophys. 31 357-396.

Monsalve G, Sheehan A, Schulte-Pelkum V, Rajaure S, Pandey M R and Wu F 2006 Seismicity and one dimensional velocity structure of the Himalayan collision zone: Earthquakes in the crust and upper mantle; J. Geophys. Res. 111(B10301), doi: 10.1029/2005JB004062.

$\mathrm{Ni} \mathrm{J}$ and Barazangi M 1984 Seismotectonics of the Himalayan collision zone: Geometry of the underthrusting Indian Plate beneath the Himalaya; J. Geophys. Res. 89 1147-1163.

Owens T J and Zandt G 1997 The implications of crustal property variations on models of Tibetan Plateau evolution; Nature 387 37-43.

Patriat P and Achache J 1984 India-Eurasia collision chronology has implications for crustal shortening and driving mechanism for plates; Nature 311 615621.

Peltzer G and Tapponnier P 1988 Formation and evolution of strike-slip faults, rifts, and basins during the India-Asia collision: An experimental approach; J. Geophys. Res. 93 $15,085-15,117$.

Pinet P and Souriau M 1988 Continental erosion and largescale relief; Tectonics 7 563-582.

Raju K, Ramprasad T, Rao P, Ramalingeswara Rao B and Varghese J 2004 New insights into the tectonic evolution of the Andaman Basin, northeast Indian Ocean; Earth Planet. Sci. Lett. 221 145-167.

Rao M B R 1973 The subsurface geology of the IndoGangetic plains; J. Geol. Soc. India $14217-242$.

Rastogi B K, Singh J and Verma R K 1973 Earthquake mechanisms and tectonics of the Assam-Burma region; Tectonophys. 18 355-366.

Rastogi B K 1974 Earthquake mechanism and plate tectonics in Himalayan region; Tectonophys. 21 47-56.

Rastogi B K 1976 Source mechanism studies and contemporary tectonics in Himalaya and nearby regions; Bull. Int. Inst. Seismol. 14 99-134.

Richardson R M 1992 Ridge forces, absolute plate motions, and the intraplate stress field; J. Geophys. Res. 97 $11,739-11,749$.

Sandiford M, Coblentz D and Richardson R M 1995 Focusing ridge-torques during continental collision in the IndoAustralian plate; Geol. 23 653-656.

Sastri V V, Bhandari L L, Raju A T R and Datta A K 1971 Tectonics framework and subsurface stratigraphy of the Ganga basin; J. Geol. Soc. India 12 232-233.

Schluter H U, Gaedicke C, Roeser H A, Schreckenberger B, Meyer H, Reichert C, Djajadihardja Y and Prexl A 2002 Tectonic features of the southern Sumatra-western Java forearc of Indonesia; Tectonics 21(11) 1-15.

Sclater J G and Fisher R L 1974 The evolution of the East Central Indian Ocean with emphasis on the tectonic setting of the ninety East Ridge; Geol. Soc. Am. Bull. 85 693-702. 
Searle M P 1991 Geology and tectonics of the Karakoram mountains; Geol. Mag. 129(2) 251-254.

Searle M P and Rex A J 1989 Thermal model for the Zanskar Himalaya; J. Metamor. Geol. 7 127-134, doi: 10.1111/ j.1525-1314.1989.tb00579.x.

Seeber L and Pêcher A 1998 Strain partitioning along the Himalayan arc and the Nanga Parbat Antiform; Geol. 26 791-794.

Seeber L, Armbruster J and Quittmeyer R 1981 Seismicity and continental subduction in the Himalayan arc; In: Zagros, Hindu Kush, Himalaya: Geodynamic evolution (eds) H K Gupta and F M Delany, Am. Geophys. Uni. Geod. Ser. 3 215-242.

Singh D D and Gupta H K 1980 Source dynamics of two great earthquakes of Indian subcontinent - the Bihan Jan. 15, 1934 and Quetta earthquake of May 30, 1935; Bull. Seismol. Soc. Am. 70 757-773.

Sinha S and Mohanty S 2012 Spatial variation of crustal strain in the Kachchh region, India: Implication on the Bhuj earthquake of 2001; J. Geod. 61 1-11, doi: 10.1016/j. jog.2012.07.003.

Sinha S, Khan P K and Mohanty S P 2013 Incidences of moderate to large intraplate earthquakes in peninsular India with special reference to $2001 \mathrm{M}_{\mathrm{w}} 7.3 \mathrm{Bhuj}$ event; Proceedings of the National Conference on Recent Advances in Mathematics and its Applications, I.S.M. Dhanbad, pp. 255-271.

Soofi M A and King S D 2002 Oblique convergence between India and Eurasia; J. Geophys. Res. 107(B5), doi: 10. 1029/2001JB000636.

Stern R J 2002 Subduction zones; Rev. Geophys. 40 31-38.

Summerfield M A and Hulton N J 1994 Natural controls of fluvial denudation rates in major world drainage basin; J. Geophys. Res. 99(7) 13,871-13,883.

Takada Y and Matsu'ura M 2004 A unified interpretation of vertical movement in Himalaya and horizontal deformation in Tibet on the basis of elastic and viscoelastic dislocation theory; Tectonophys. 383 105-131.

Tandon A N 1972 Anantnag earthquakes (February-April 1967); Ind. J. Meteor. Geophys. 23 491-502.

Tandon A N and Srivastava H N 1975 Focal mechanisms of some recent Himalayan earthquakes and regional plate tectonics; Bull. Seismol. Soc. Am. 65 963-969.
Tapponnier P, Zhiqin X, Roger F, Meyer B, Arnaud N, Wittlinger $G$ and Jingsui Y 2001 Oblique stepwise rise and growth of the Tibetan plateau; Sci. 294(5547) $1671-1677$.

Tiwari V M, Vyghreswara Rao M B S, Mishra D C and Singh B 2006 Crustal structure across Sikkim, NE Himalaya from new gravity and magnetic data; Earth Planet. Sci. Lett. 247 61-69.

Turcotte D L and Schubert G 1982 Geodynamics applications of continuum physics to geological problems; Wiley, New York, 450p.

Valdiya K S 1976 Himalaya transverse faults and their parallelism with subsurface structures of north Indian planes; Tectonophys. 32 353-386.

Valdiya K S 1980 Geology of Kumaun Lesser Himalaya; Him. Geol., 291p.

Verma R K and Kumar G V R K 1987 Seismicity and the nature of plate movement along the Himalayan arc, northeast India and Arakan-Yoma: A review; Tectonophys. 134 $153-175$

Vilotte J P, Madariaga R, Daignières M and Zienkiewicz O C 1986 Numerical study of continental collision: Influence of buoyancy forces and an initial stiff inclusion; Geophys. J. Roy. Astron. Soc. 84 279-310.

Weissel J K, Anderson R N and Geller C A 1980 Deformation of the Indo-Australian plate; Nature 287 284-291, doi: $10.1038 / 287284 a 0$.

Whipple K X and Meade B J 2006 Orogen response to changes in climatic and tectonic forcing; Earth Planet. Sci. Lett. 243 218-228.

Willett S, Beaumont C and Fullsack P 1993 Mechanical model for the tectonics of doubly vergent compressional orogens; Geol. 21 371-374.

Wobus C, Heimsath A, Whipple K and Hodges K 2005 Active out-of-sequence thrust faulting in the central Nepalese Himalaya; Nature 434, doi: 10.1038/ nature03454.

Yin A 2006 Cenozoic tectonic evolution of the Himalayan orogen as constrained by along-strike variation of structural geometry, exhumation history, and foreland sedimentation; Earth Sci. Rev. 76 1-131.

Yin A and Harrison M 2000 Geologic evolution of the Himalayan-Tibetan orogen; Ann. Rev. Earth Planet. Sci. 28 211-280. 